\title{
Ancient European Lakes: Reservoirs of Hidden Microbial Diversity? The Case of Lake Pamvotis (NW Greece)
}

\author{
Anastasia Touka', Katerina Vareli1,2, Maria Igglezou ${ }^{1}$, Nikolaos Monokrousos ${ }^{2}$, \\ Dimitrios Alivertis ${ }^{2}$, John M. Halley², Sotiris Hadjikakou ${ }^{3}$, Stathis Frillingos ${ }^{4}$, Ioannis Sainis ${ }^{1,2^{*}}$
}

\begin{abstract}
${ }^{1}$ Interscience Molecular Oncology Laboratory (iMol), Cancer Biobank Center (UICBC), University of Ioannina, Ioannina, Greece ${ }^{2}$ Department of Biological Applications and Technology, School of Health Sciences, University of Ioannina, Ioannina, Greece ${ }^{3}$ Department of Chemistry, Section of Inorganic and Analytical Chemistry, University of Ioannina, Ioannina, Greece ${ }^{4}$ Department of Medicine, School of Health Sciences, Laboratory of Biological Chemistry, University of Ioannina, Ioannina, Greece

Email: atouka@cc.uoi.gr, kvareli@cc.uoi.gr, mariaig473@gmail.com, dimitris.alivertis@gmail.com, jhalley@cc.uoi.gr, shadjika@uoi.gr, efriligo@uoi.gr,nmonokro@bio.auth.gr, *isainis@cc.uoi.gr
\end{abstract}

How to cite this paper: Touka, A., Vareli, K., Igglezou, M., Monokrousos, N., Alivertis, D., Halley, J.M., Hadjikakou, S., Frillingos, S. and Sainis, I. (2018) Ancient European Lakes: Reservoirs of Hidden Microbial Diversity? The Case of Lake Pamvotis (NW Greece). Open Journal of Ecology, 8, 537-578.

https://doi.org/10.4236/oje.2018.810033

Received: October 8, 2018

Accepted: October 28, 2018

Published: October 31, 2018

Copyright ( 2018 by authors and Scientific Research Publishing Inc. This work is licensed under the Creative Commons Attribution International License (CC BY 4.0).

http://creativecommons.org/licenses/by/4.0/

(c) (i) Open Access

\begin{abstract}
Ancient European lakes are clustered within a radius of $300 \mathrm{~km}$ around Lake Ohrid. Information concerning microbial diversity in these lakes is limited. We studied diversity of the dominant prokaryotic phylotypes in the sediments in one of these lakes, known as Lake Pamvotis. The analysis was performed in samples from two stations for four seasons of the same year. DNA extraction followed by PCR amplification (16S rDNA), Denaturing Gradient Gel Electrophoresis, cloning and sequencing was applied in order to reveal the sequence signatures of the dominant bacterial and archaeal phylotypes. Bacterial and archaeal cell numbers were quantified by real-time PCR. Several environmental variables measured in parallel, including $\mathrm{pH}$, Nickel, Chromium, Arsenic, Calcium, Total Nitrogen and Total Carbon, were found to affect strongly the prokaryotic abundances. Most of the identified sequences of Bacteria belong to Proteobacteria and most of the sequences of Archaea belong to Euryarchaeota. The great majority of these bacterial (84.21\%) and archaeal sequences $(95.65 \%)$ have no cultivated counterparts in the databases. In addition, many of these bacterial (50.88\%) and archaeal sequences (20.65\%) correspond to potentially new species. Six of the bacterial sequences constitute a new class of Cyanobacteria which we have named "Lake Pamvotis cluster" (LPC). Our findings highlight Lake Pamvotis as a habitat for several previously unidentified species of Bacteria and Archaea.
\end{abstract}

\section{Keywords}

Ancient Lakes, Lake Pamvotis, Bacteria, Archaea 


\section{Introduction}

Worldwide ancient lakes such as Baikal, Tanganyika, Victoria, Titicaca represent "natural laboratories" for evolutionary research and major hotspots of biological diversity [1] [2] [3]. In the European continent, few lakes are old enough to feature endemic species. All of them are restricted to the Balkan Region, a mountainous area in southeastern Europe that has long been recognized as a worldwide hotspot of endemic freshwater biodiversity [4] [5]. The most prominent of these lakes is Lake Ohrid and its sister Lake Prespa with a limnological age of 2 5 million years [6] [7]. The majority of all ancient or putatively ancient European lakes are thought to be restricted within a radius of $300 \mathrm{~km}$ around Lakes Ohrid and Prespa [5]. This cluster of lakes includes less well known, potentially ancient lakes such as the lakes Skutari (Montenegro, Albania), Mikri Prespa (Greece, Albania), Vegoritis (Greece), Trichonis and the ancient lake Pamvotis (Greece) (Figure 1) [2] [8] [9] [10].

Lake Pamvotis has been in existence throughout the Plio-Pleistocene period, as shown by the identification of several endemic mollusc taxa which are known to be 500,000 years old [4]. Therefore, it has attracted research interests as a sedimentary archive on long term environmental and climate history and as a hotspot for European biodiversity. Lake Pamvotis has also been characterized as a Quaternary refugium, that is an ecologically stable area critical not only for the long-term survival of existing species, but also for the emergence of new ones (Figure 1) [11].

Unfortunately, microbial diversity has not been extensively studied either in Lake Pamvotis or in other lakes of the wider region. The few studies conducted were mainly focusing on the problems of gradual eutrophication and urbanization in some of these lakes [12] [13] [14] [15]. Nevertheless, the results are

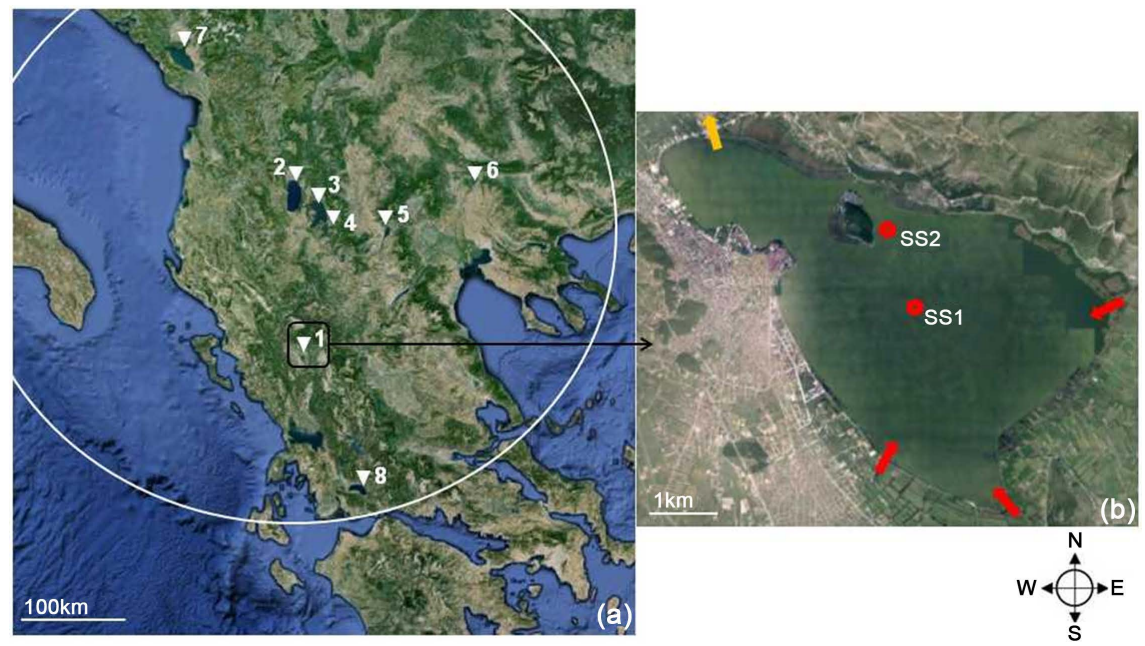

Figure 1. (a) Within a radius of $300 \mathrm{~km}$ (white cycle) around Lake Ohrid, are thought to be restricted the most ancient or putatively ancient European lakes [5] (1: Pamvotis, 2: Ohrid, 3: Megali Prespa, 4: Mikri Prespa, 5: Vegoritis, 6: Doirani, 7: Skutari, 8: Trichonis); (b) Sample Stations (SS) in Lake Pamvotis are indicated by dots. Main inflows and outflows are indicated by arrows. 
interesting. Molecular data reveal that the population of the filamentous Cyanobacteria from Lake Pamvotis is homogeneous, but divergent from other populations worldwide [13]. In the nearby Lake Ziros, all cyanobacterial phylotypes except the ones of three cosmopolitan species (Planktothrix sp., Anabaena sp., Microcystis $s p$.) were found to have low homology to any other known cyanobacterial species [12]. In addition, strains of Limnothrix redekei from Lake Kastoria, a potentially ancient lake in the same region, form a separate phylogenetic group within the Cyanobacteria [16]. Novel phylotypes belonging to the Chroococcales were recognized recently in lakes Kastoria and Doirani [14]. Bacterial diversity in the water and sediment of lake Kastoria was found to be high, consisting mostly of yet uncultured Bacteria, whereas $11 \%$ of the water column and $5 \%$ of the sediment bacterial phylotypes could not be classified with any of the known bacterial phyla [15]. The results from those studies indicate the existence of a significant hidden microbial diversity in these ancient ecosystems. However, a systematic study of the bacterial diversity has not been undertaken to date in any of these lakes and; in addition, the abundance and diversity of Archaea has not been investigated at all. In this study, we present a systematic analysis of both the bacterial and the archaeal dominant phylotypes in the sediments of Lake Pamvotis.

Our study addresses three important questions on the organization of this aquatic microbial ecosystem: 1) Are there novel, previously unidentified, bacterial and archaeal species among the dominant phylotypes? 2) Are archaeal communities a quantitatively important component of microbial communities inhabiting this environment? 3) Is there a correlation between physicochemical variables, prokaryotic abundance and diversity of the dominant phylotypes?

\section{Materials and Methods}

\subsection{Sampling Sites and Sample Collection}

Lake Pamvotis is a closed hydrological system. It lies approximately at $39^{\circ} 40^{\prime} \mathrm{N}$, $20^{\circ} 53^{\prime} \mathrm{E}$, at 470 meters above sea-level in the mountainous region of the Pindus. It is a shallow lake (4.23 m average depth) and has a surface area of about $22.8 \mathrm{~km}^{2}$ [13].

Sediment samples (top $5-10 \mathrm{~cm}$ ) were collected using a grab sampler at two sampling stations (SS): SS1 and SS2. SS1 is situated approximately in the middle of the lake (depth 6.5 to $7.5 \mathrm{~m}$ depending on the season) and SS2 is a station where the maximum depth of the lake was measured ( 8.5 to $9.5 \mathrm{~m}$ depending on the season) (Figure 1). Temperature was measured in water just above the sediment by a depth sampling device with a built-in thermometer (Windaus, Labortechnic, GmbH 7 Co.KG). By using a GPS instrument, we collected samples from the same sites once per season over a one-year period (the year 2012). Once retrieved onboard, sediments were homogenized and sub-sampled in sterilized Falcon tubes for DNA extraction and for physicochemical analysis. Subsamples were transported to the laboratory in a portable freezer in less than an hour. 


\subsection{Chemical Analysis of Sediment Samples}

Sediment samples were dried at $70^{\circ} \mathrm{C}$ for $24 \mathrm{~h}$ upon arrival to the laboratory.

For the $\mathrm{pH}$ measurements, sediment samples were diluted in $1 \mathrm{M} \mathrm{KCl} \mathrm{(1:2} \mathrm{se-}$ diment to solution ratio) and a Hanna $\mathrm{pH}$ meter was used (Hanna Instruments pH211) [17].

Two grams of each sample were extracted twice with $20 \mathrm{~mL}$ of bidistilled water, for anions $\left(\mathrm{Cl}^{-}, \mathrm{SO}_{4}{ }^{2-}\right)$ analysis, and $20 \mathrm{~mL}$ of $40 \mathrm{mM}$ nitric acid aqueous solution, for cations $\left(\mathrm{Na}^{+}, \mathrm{K}^{+}, \mathrm{Ca}^{2+}, \mathrm{Mg}^{2+}\right)$ analysis, in an ultrasonic bath for $30 \mathrm{~min}$. The extracts were centrifuged, combined and diluted in bidistilled water to a volume of $50 \mathrm{~mL} .20 \mu \mathrm{L}$ of each sample were injected in HPLC equipped with a conductivity detector (Shimadzu CDD-10A VP). For the determination of cations IC YK-421 column with a Shodex IC YK-G column guard and anions IC NI-424 column with IC NI-G column guard in a Shimadzu CTO-10AC column oven were used with shipping solvent. Standard solutions of the above ions at concentrations ranging from 1 to $100 \mathrm{mg} / \mathrm{L}$ in seven levels were analyzed as external calibration basis quantification [18].

Total carbon (TC) and total organic carbon (TOC) were analyzed with a Shimadzu TOC-VCPH carbon analyzer (Shimadzu, Japan), coupled to a solid state combustion unit (model SSM-5000A). One gram of dried sample was inserted in solid state combustion unit. For TC the unit uses catalytically aided combustion oxidation at $900^{\circ} \mathrm{C}$ method and for inorganic carbon (IC) pre-acidification, with oven temperature $250^{\circ} \mathrm{C}$. After the treatment in the solid state combustion unit, samples were automatically inserted directly in the carbon analyzer, which measures the TC and IC. TOC was derived by subtracting the IC from the TC.

The total nitrogen in the sediment (TN) was determined spectrophotometrically by Total Kjeldahl (Nessler method) after digestion by the HACH Digesdahl Apparatus together with $3 \mathrm{~mL} \mathrm{H}_{2} \mathrm{SO}_{4}(98 \% \mathrm{v} / \mathrm{v})$ at $450^{\circ} \mathrm{C}$, while for the amendment of the digest the $\mathrm{HACH}$ method 8075 was used. The concentration of TN within the sample was measured in a HACH DR/2010 Spectrophotometer at the wavelength of $460 \mathrm{~nm}$. The total phosphorous content (TP) in the sediment was determined by the molybdenum blue method ( $\mathrm{HACH})$ [19].

Heavy metals $\mathrm{Sb}, \mathrm{Ni}, \mathrm{Hg}, \mathrm{Se}, \mathrm{Cd}, \mathrm{Mn}, \mathrm{Pb}, \mathrm{Fe}, \mathrm{Cu}, \mathrm{Cr}, \mathrm{Zn}$ and As were determined using ICP-AES (Thermo Scientific iCAP 6300 ICP Spectrometer) according to the methodology described by Ashley et al. [20].

\subsection{Isolation of Culturable Bacteria}

For the isolation of culturable bacterial species, R2A plates (LABM, United Kingdom) were prepared according to the manufacturer's instructions. R2A medium was used for a general view of culturable freshwater Bacteria. Ten grams of sediment samples taken during summer from both stations were suspended in sterile water. A series of 10-fold dilutions were prepared. R2A medium plates were inoculated with $100 \mu \mathrm{L}$ aliquots from different dilutions as described earlier [21]. Plates were incubated at $26^{\circ} \mathrm{C}$ (since bottom water tempera- 
ture during summer ranged from $24^{\circ} \mathrm{C}$ to $26^{\circ} \mathrm{C}$, Table 1) for 10 days in the dark. Bacterial colonies were selected based on morphological features and color [22].

\subsection{DNA Extraction, PCR Amplification and Quantitative Real-Time PCR}

DNA was extracted from the sediment samples using an UltraClean soil DNA isolation kit from MoBio Laboratories (PowerSoil DNA Isolation kit, Carlsbad, CA 92010) in accordance with the manufacturer's instructions.

PCR amplification was performed in a Biorad iCycler in a $50 \mu \mathrm{L}$ reaction volume. For archaeal $16 \mathrm{~S}$ rDNA amplification, a $344 \mathrm{~F}-\mathrm{GC}$ and $915 \mathrm{R}$ primer set was used and a touchdown PCR was performed as described earlier [23].

For bacterial $16 \mathrm{~S}$ rDNA amplification a $341 \mathrm{~F}-\mathrm{GC}$ and $907 \mathrm{R}$ primer set was used and a touchdown PCR was performed as described earlier [24].

PCR products for both Archaea and Bacteria 16S rDNA were evaluated in a $1 \%(w / v)$ agarose gel electrophoresis and subsequently used for Denaturing Gradient Gel Electrophoresis (DGGE).

For quantification of archaeal and bacterial 16S rRNA genes in our samples, serial 10-fold dilutions of recombinant plasmids containing a partial fragment of an archaeal and a bacterial 16S rDNA respectively were used as external standards, to obtain a reference curve. The standard dilutions ranged from $10^{3}$ to $10^{5}$ and from $10^{4}$ to $10^{10}$ for archaeal and bacterial reference curves, respectively.

The real-time PCR was performed in a LightCycler 480 (Roche) instrument using the LightCycler 480 SYBR Green Master I (Roche) following the manufacturer's instructions. The final $20 \mu \mathrm{L}$ reaction mix contained $10 \mu \mathrm{L}$ of the SYBR Green Master Mix I, the original primer set (in case of Forward primers without the GC clamp) for Bacteria and Archaea and an appropriate dilution of the DNA samples were initially incubated at $95^{\circ} \mathrm{C}$ for 5 min followed by 40 cycles of a 3-step cycling at $95^{\circ} \mathrm{C}$ for $45 \mathrm{~s}$ (denaturation), $61^{\circ} \mathrm{C}$ for $45 \mathrm{~s}$ for Archaea or $60^{\circ} \mathrm{C}$ for $45 \mathrm{~s}$ for Bacteria (annealing), $72^{\circ} \mathrm{C}$ for $45 \mathrm{~s}$ (extension) and a final extension for $10 \mathrm{~min}$ at $72^{\circ} \mathrm{C}$. All samples, standards and negative controls were tested in triplicates. Finally, we used CT values to determine the $16 \mathrm{~S}$ rDNA copy numbers in our samples and we converted them into cell numbers assuming that archaeal cells contain 2 and bacterial cells contain 3.8 16S rDNA copies per cell [25].

\subsection{Denaturing Gradient Gel Electrophoresis (DGGE), Cloning and Sequencing}

DGGE for Archaea and Bacteria was performed as described earlier by Muyzer et al. [26] with minor modifications as described by Janse et al. [13] [27]. We used a denaturing gradient $20 \%-70 \%$ and $20 \%-60 \%$ for Archaea and Bacteria respectively. Bands were detected after ethidium bromide staining, excised and incubated in $50 \mu \mathrm{L}$ sterile MilliQ water $\mathrm{O} / \mathrm{N}$ at $4^{\circ} \mathrm{C}$. A new PCR was performed using the eluent and the original primer set and run on a DGGE gel to confirm its identity. The PCR products were purified using a Macherey-Nagel DNA clean-up kit (NucleoSpin Gel and PCR Clean-up, Duren-Germany), and 
Table 1. Physical-chemical properties of Lake Pamvotis sediments.

\begin{tabular}{cccccccc}
\hline & $\begin{array}{c}\text { Depth } \\
(\mathrm{m})\end{array}$ & $\mathrm{T} \cdot \mathrm{C}$ & $\mathrm{pH}$ & $\begin{array}{c}\mathrm{TC} \\
(\mathrm{mg} / \mathrm{g})\end{array}$ & $\begin{array}{c}\text { TOC } \\
(\mathrm{mg} / \mathrm{g})\end{array}$ & $\begin{array}{c}\text { TP } \\
(\mathrm{mg} / \mathrm{g})\end{array}$ & $\begin{array}{c}\text { TN } \\
(\mathrm{mg} / \mathrm{g})\end{array}$ \\
\hline Spring, SS1 & $8.40 \pm 0.20$ & $20 \pm 0.50$ & $6.96 \pm 0.02$ & $67.54 \pm 7.26$ & $60.69 \pm 3.13$ & $3.02 \pm 0.02$ & $2.94 \pm 0.01$ \\
Spring, SS2 & $9.30 \pm 0.30$ & $19 \pm 0.40$ & $6.30 \pm 0.01$ & $99.79 \pm 3.53$ & $87.31 \pm 3.99$ & $4.05 \pm 0.02$ & $5.03 \pm 0.11$ \\
Summer, SS1 & $7.30 \pm 0.15$ & $26 \pm 0.70$ & $7.07 \pm 0.01$ & $68.58 \pm 2.31$ & $65.00 \pm 2.01$ & $4.83 \pm 0.05$ & $3.91 \pm 0.03$ \\
Summer, SS2 & $8.20 \pm 0.18$ & $24 \pm 0.50$ & $6.31 \pm 0.01$ & $99.53 \pm 2.07$ & $93.70 \pm 4.09$ & $4.13 \pm 0.02$ & $3.33 \pm 0.02$ \\
Autumn, SS1 & $8.10 \pm 0.25$ & $11 \pm 0.50$ & $7.08 \pm 0.01$ & $67.39 \pm 2.42$ & $63.54 \pm 2.56$ & $10.01 \pm 0.09$ & $3.99 \pm 0.03$ \\
Autumn, SS2 & $9.00 \pm 0.20$ & $12 \pm 0.50$ & $6.23 \pm 0.02$ & $65.60 \pm 1.01$ & $61.30 \pm 1.96$ & $9.69 \pm 0.08$ & $5.01 \pm 0.05$ \\
Winter, SS1 & $8.40 \pm 0.10$ & $6 \pm 0.10$ & $7.18 \pm 0.20$ & $59.73 \pm 3.60$ & $58.19 \pm 2.12$ & $10.75 \pm 0.42$ & $3.94 \pm 0.03$ \\
Winter, SS2 & $9.30 \pm 0.40$ & $6 \pm 0.20$ & $6.45 \pm 0.02$ & $79.80 \pm 11.14$ & $79.60 \pm 1.02$ & $8.78 \pm 0.05$ & $5.80 \pm 0.01$ \\
\hline
\end{tabular}

(a)

\begin{tabular}{ccccccc}
\hline & $\begin{array}{c}\mathrm{Na}^{+} \\
(\mathrm{mg} / \mathrm{kg})\end{array}$ & $\begin{array}{c}\mathrm{K}^{+} \\
(\mathrm{mg} / \mathrm{kg})\end{array}$ & $\begin{array}{c}\mathrm{Ca}^{2+} \\
(\mathrm{mg} / \mathrm{kg})\end{array}$ & $\begin{array}{c}\mathrm{Mg}^{2+} \\
(\mathrm{mg} / \mathrm{kg})\end{array}$ & $\begin{array}{c}\mathrm{Cl}^{-} \\
(\mathrm{mg} / \mathrm{kg})\end{array}$ & $\begin{array}{c}\mathrm{SO}_{4}{ }^{2-} \\
(\mathrm{mg} / \mathrm{kg})\end{array}$ \\
\hline Spring, SS1 & $4.96 \pm 0.01$ & $4.17 \pm 0.01$ & $37.69 \pm 0.02$ & $13.06 \pm 0.04$ & $64.34 \pm 0.02$ & $296.62 \pm 0.04$ \\
Spring, SS2 & $6.09 \pm 0.01$ & $5.41 \pm 0.01$ & $72.15 \pm 0.26$ & $17.83 \pm 0.01$ & $117.82 \pm 0.70$ & $537.42 \pm 0.10$ \\
Summer, SS1 & $4.87 \pm 0.01$ & $4.34 \pm 0.01$ & $50.04 \pm 0.02$ & $14.48 \pm 0.03$ & $64.66 \pm 0.02$ & $554.17 \pm 0.03$ \\
Summer, SS2 & $5.54 \pm 0.01$ & $5.98 \pm 0.01$ & $76.34 \pm 0.79$ & $19.41 \pm 0.04$ & $103.95 \pm 0.18$ & $386.02 \pm 0.12$ \\
Autumn, SS1 & $4.91 \pm 0.01$ & $5.57 \pm 0.03$ & $49.19 \pm 0.12$ & $18.73 \pm 0.02$ & $70.17 \pm 0.01$ & $431.68 \pm 0.02$ \\
Autumn, SS2 & $6.33 \pm 0.01$ & $5.86 \pm 0.01$ & $70.98 \pm 0.02$ & $18.95 \pm 0.03$ & $109.87 \pm 0.09$ & $589.16 \pm 0.03$ \\
Winter, SS1 & $3.39 \pm 0.01$ & $5.56 \pm 0.01$ & $57.28 \pm 0.02$ & $16.33 \pm 0.02$ & $35.35 \pm 0.02$ & $450.01 \pm 0.03$ \\
Winter, SS2 & $3.62 \pm 0.02$ & $5.02 \pm 0.02$ & $51.26 \pm 0.73$ & $16.32 \pm 0.02$ & $51.16 \pm 0.04$ & $428.55 \pm 0.07$ \\
\hline
\end{tabular}

(b)

\begin{tabular}{|c|c|c|c|c|c|c|}
\hline & $\begin{array}{c}\mathrm{Sb} \\
(\mathrm{mg} / \mathrm{kg})\end{array}$ & $\begin{array}{c}\mathrm{Ni} \\
(\mathrm{mg} / \mathrm{kg})\end{array}$ & $\begin{array}{c}\mathrm{Hg} \\
(\mathrm{mg} / \mathrm{kg})\end{array}$ & $\begin{array}{c}\mathrm{Se} \\
(\mathrm{mg} / \mathrm{kg})\end{array}$ & $\begin{array}{c}\mathrm{Cd} \\
(\mathrm{mg} / \mathrm{kg})\end{array}$ & $\begin{array}{c}\mathrm{Mn} \\
(\mathrm{mg} / \mathrm{kg})\end{array}$ \\
\hline Spring, SS1 & $5.10 \pm 0.08$ & $132.00 \pm 0.25$ & $1.13 \pm 0.01$ & $<6.00$ & $<4.00$ & $1090.00 \pm 22.00$ \\
\hline Spring, SS2 & $2.43 \pm 0.02$ & $98.00 \pm 1.75$ & $1.59 \pm 0.01$ & $<6.00$ & $<4.00$ & $959.00 \pm 10.00$ \\
\hline Summer, SS1 & $2.85 \pm 0.02$ & $126.00 \pm 0.20$ & $0.16 \pm 0.01$ & $<6.00$ & $<4.00$ & $1130.00 \pm 35.00$ \\
\hline Summer, SS2 & $2.78 \pm 0.01$ & $97.10 \pm 1.53$ & $0.84 \pm 0.02$ & $<6.00$ & $<4.00$ & $843.00 \pm 21.00$ \\
\hline Autumn, SS1 & $2.89 \pm 0.01$ & $123.00 \pm 0.17$ & $0.44 \pm 0.01$ & $<6.00$ & $<4.00$ & $1330.00 \pm 76.00$ \\
\hline Autumn, SS2 & $2.72 \pm 0.02$ & $96.50 \pm 1.20$ & $0.95 \pm 0.01$ & $<6.00$ & $<4.00$ & $923.00 \pm 15.00$ \\
\hline Winter, SS1 & $3.32 \pm 0.02$ & $135.00 \pm 0.22$ & $0.18 \pm 0.01$ & $<6.00$ & $<4.00$ & $950.00 \pm 15.00$ \\
\hline Winter, SS2 & $3.52 \pm 0.02$ & $88.50 \pm 2.70$ & $<0.10$ & $<6.00$ & $<4.00$ & $999.00 \pm 32.00$ \\
\hline
\end{tabular}

(c)

\begin{tabular}{|c|c|c|c|c|c|c|}
\hline & $\begin{array}{c}\mathrm{Pb} \\
(\mathrm{mg} / \mathrm{kg})\end{array}$ & $\begin{array}{c}\mathrm{Fe} \\
(\mathrm{mg} / \mathrm{kg})\end{array}$ & $\begin{array}{c}\mathrm{Cu} \\
(\mathrm{mg} / \mathrm{kg})\end{array}$ & $\begin{array}{c}\mathrm{Cr} \\
(\mathrm{mg} / \mathrm{kg})\end{array}$ & $\begin{array}{c}\mathrm{Zn} \\
(\mathrm{mg} / \mathrm{kg})\end{array}$ & $\begin{array}{c}\text { As } \\
(\mathrm{mg} / \mathrm{kg})\end{array}$ \\
\hline Spring, SS1 & $<30.0$ & $25200.00 \pm 58.00$ & $31.40 \pm 1.10$ & $83.10 \pm 2.87$ & $81.30 \pm 1.99$ & $2.76 \pm 0.01$ \\
\hline Spring, SS2 & $<30.0$ & $25500.00 \pm 61.00$ & $31.80 \pm 0.90$ & $59.40 \pm 2.12$ & $89.90 \pm 3.22$ & $4.58 \pm 0.02$ \\
\hline Summer, SS1 & $<30.0$ & $27600.00 \pm 32.00$ & $32.10 \pm 0.70$ & $83.60 \pm 2.66$ & $93.00 \pm 1.42$ & $1.88 \pm 0.01$ \\
\hline Summer, SS2 & $<30.0$ & $26400.00 \pm 59.00$ & $32.10 \pm 1.20$ & $66.00 \pm 1.89$ & $91.50 \pm 2.89$ & $4.44 \pm 0.03$ \\
\hline Autumn, SS1 & $<30.0$ & $28100.00 \pm 45.00$ & $30.60 \pm 0.50$ & $81.70 \pm 1.57$ & $90.10 \pm 1.08$ & $2.40 \pm 0.02$ \\
\hline Autumn, SS2 & $<30.0$ & $23600.00 \pm 52.00$ & $31.00 \pm 0.20$ & $63.60 \pm 1.75$ & $97.00 \pm 3.55$ & $4.37 \pm 0.01$ \\
\hline Winter, SS1 & $<30.0$ & $28200.00 \pm 42.00$ & $34.00 \pm 0.90$ & $79.20 \pm 1.28$ & $97.00 \pm 2.80$ & $2.14 \pm 0.01$ \\
\hline Winter, SS2 & $<30.0$ & $21000.00 \pm 20.00$ & $37.00 \pm 0.40$ & $58.40 \pm 1.97$ & $78.70 \pm 1.43$ & $4.80 \pm 0.02$ \\
\hline
\end{tabular}

Physicochemical properties of the sediments in Lake Pamvotis sample station 1 (SS1) and 2 (SS2). (a) Depth, T, pH, Carbon, Nitrogen and Phosphorous contents; (b) Major anions and cations; c) Heavy metals. Heavy metal concentrations exceeding the PEC or TEC limits are indicated in bold (Ni PEC: 48.6 mg/kg, Hg PEC: 1.06 mg/kg, Hg TEC: 0.18 mg/kg, Cr TEC: 43.4 mg/kg, Cu TEC: 31.6 mg/kg) [36]. 
afterwards they were cloned using a TOPO TA cloning Kit (Invitrogen, USA) according to the manufacturer's instructions. Subsequently, ten recombinant clones from each library (corresponding to each DGGE band) were randomly picked for further analysis. Inserts were digested with restriction enzyme HaeIII (HT Biotechnology Ltd, Cambridge, United Kingdom) in order to identify different Restriction Fragment Length Polymorphisms (RFLPs) [28]. Clones with different restriction patterns were sequenced at both strands. Sequencing was performed by Eurofins Genomics/VBC Biotech (Austria) [13] [28].

\subsection{Nucleotide Sequences and Accession Numbers}

The final sequences were deposited at GenBank and were assigned accession numbers KC510289-KC510380 for Archaea, KP244158-KP244214 for Bacteria and KU862661-KU862683 for cultured isolates.

\subsection{Phylogenetic Trees and Statistical Analysis}

All sequences were compared against GenBank using BLAST in order to obtain their phylogenetic affiliation. Phylogenetic analyses were performed with MEGA6.1 software. Trees were constructed using the Neighbor-Joining method with Jukes-Cantor distance correction [29].

Spearman's correlation coefficient was used to investigate possible relationships among bacterial and archaeal abundances and the physicochemical variables. All statistical analyses were conducted with STATISTICA 7 (Tulsa, OK, USA).

\section{Results and Discussion}

\subsection{Physical-Chemical Properties of Lake Pamvotis Sediments}

Total Carbon (TC), Total Organic Carbon (TOC), Total Nitrogen (TN) and Total Phosphorus (TP) concentrations (Table 1) are in accordance to previously published studies underlining the eutrophic status of the lake [19] [30] [31]. Moreover, TN, TP and TOC concentrations in Lake Pamvotis sediments are comparable to those measured in other lakes worldwide [32] [33] [34] [35].

Concerning heavy metal concentrations, according to the Sediment Quality Guidelines (SQGs) [36], only Ni concentrations exceeded the Probable Effect Concentration (PEC) in Lake Pamvotis sediments in both stations during all seasons. Mercury concentrations exceeded PEC only at spring. Two other heavy metals $(\mathrm{Cr}$ and $\mathrm{Cu})$ were found to exceed the Threshold Effect Concentration (TEC) (Table 1).

In a previous study conducted between 1991-1993 heavy metal concentrations had been measured in surface sediment samples from Lake Pamvotis stations SS1 and SS2 [37]. It appears that the average Ni concentration in the lake has been increased between 1991 [37] and 2012 (our current study). More specifically, the Ni concentration is 4.7- to 5.1-fold higher than 1991-1993 in SS1 and 1.8- to 2.0-fold higher in SS2. 
Nickel and $\mathrm{Cr}$ input in lake sediments are possibly enhanced either by mining activities [38] or by incompletely treated industrial and municipal wastewaters, agrochemicals, landfill leachates [39]. In the case of Lake Pamvotis, a municipal wastewater treatment plant exists since 1992, the industrial and agricultural activities have declined since 1990 and there are no mining activities. Thus, the most reasonable explanation for the elevated amounts of $\mathrm{Ni}$ at present times is the accumulation of geogenic material draining from the SE due to the construction of a four-km long tunnel at the Mitsikeli Mountain in years 1999-2007.

Mercury (Hg) concentrations in Lake Pamvotis sediments remains stable relative to the concentrations measured previously (1991-1993) [37]. Concerning the presence of As in both stations we cannot speculate on the origins, due to the lack of previous studies.

In a recent study [40], Lake Pamvotis sediments have been characterized as moderately to severely contaminated with heavy metals. Municipal wastewater, silver smithy and operation of leather tanneries from the $17^{\text {th }}$ until the mid- $20^{\text {th }}$ century are assumed to be the main reasons for metal contamination [40].

\subsection{Prokaryotic Abundance in Lake Pamvotis Sediments: Bacteria vs Archaea}

The prokaryotic community in the Lake Pamvotis sediments was found to be dominated by Bacteria. Archaea accounted for $6.17 \%$ to $14.09 \%$ of the total prokaryotic $16 \mathrm{~S}$ rDNA copy number (Table 2). Taking into account the average $16 \mathrm{~S}$ rDNA copy number in archaeal (2 copies/cell) and bacterial (3.8 copies/cell) genomes [25], we can estimate that Archaea may represent $11.13 \%$ to $23.88 \%$ of the total prokaryotic cells in Lake Pamvotis (Table 2).

Our data are in agreement with previously published studies on other lakes suggesting that Archaea are not the dominant component of the prokaryotic community in freshwater sediments. In sediments of Lake Pavin, qPCR analysis

Table 2. Quantification of bacterial and archaeal cell numbers in Lake Pamvotis sediments.

\begin{tabular}{|c|c|c|c|c|c|c|}
\hline & $\begin{array}{c}\text { Bacterial } \\
\text { 16S rDNA } \\
\text { copies/g sediment }\end{array}$ & $\begin{array}{c}\text { Archaeal } \\
\text { 16S rDNA } \\
\text { copies/g sediment }\end{array}$ & $\begin{array}{l}\text { \%Archaeal } \\
\text { 16S rDNA } \\
\text { copies }\end{array}$ & $\begin{array}{c}\text { Bacteria } \\
\text { estimated cell } \\
\text { number/g sediment }\end{array}$ & $\begin{array}{c}\text { Archaea } \\
\text { estimated cell } \\
\text { number/g sediment }\end{array}$ & $\begin{array}{l}\text { \%Archaea } \\
\text { cell number }\end{array}$ \\
\hline Spring, SS1 & $3.16 \pm 0.29 \times 10^{9}$ & $2.08 \pm 0.21 \times 10^{8}$ & $6.17 \%$ & $0.83 \times 10^{9}$ & $1.04 \times 10^{8}$ & $11.13 \%$ \\
\hline Summer, SS1 & $4.52 \pm 0.24 \times 10^{9}$ & $5.24 \pm 0.18 \times 10^{8}$ & $10.38 \%$ & $1.18 \times 10^{9}$ & $2.62 \times 10^{8}$ & $18.16 \%$ \\
\hline Autumn, SS1 & $4.04 \pm 0.22 \times 10^{9}$ & $3.94 \pm 0.23 \times 10^{8}$ & $8.88 \%$ & $1.06 \times 10^{9}$ & $1.97 \times 10^{8}$ & $15.30 \%$ \\
\hline Winter, SS1 & $4.76 \pm 0.26 \times 10^{9}$ & $3.25 \pm 0.20 \times 10^{8}$ & $6.39 \%$ & $1.25 \times 10^{9}$ & $1.62 \times 10^{8}$ & $11.47 \%$ \\
\hline Spring, SS2 & $4.32 \pm 0.21 \times 10^{9}$ & $6.32 \pm 0.19 \times 10^{8}$ & $12.76 \%$ & $1.13 \times 10^{9}$ & $3.16 \times 10^{8}$ & $21.85 \%$ \\
\hline Summer, SS2 & $5.24 \pm 0.23 \times 10^{9}$ & $8.60 \pm 0.24 \times 10^{8}$ & $14.09 \%$ & $1.37 \times 10^{9}$ & $4.30 \times 10^{8}$ & $23.88 \%$ \\
\hline Autumn, SS2 & $5.68 \pm 0.28 \times 10^{9}$ & $8.12 \pm 0.26 \times 10^{8}$ & $12.54 \%$ & $1.49 \times 10^{9}$ & $4.06 \times 10^{8}$ & $21.41 \%$ \\
\hline Winter, SS2 & $5.64 \pm 0.27 \times 10^{9}$ & $7.68 \pm 0.22 \times 10^{8}$ & $11.98 \%$ & $1.48 \times 10^{9}$ & $3.84 \times 10^{8}$ & $20.96 \%$ \\
\hline
\end{tabular}

Quantification of both bacterial and archaeal 16S rDNA gene copies in Lake Pamvotis sediments, as determined by quantitative PCR assays. Bacterial and archaeal cell numbers have been estimated assuming 3.8 and 2 copies of the $16 \mathrm{~S}$ rDNA per bacterial and archaeal cell, respectively [25]. 
revealed that Archaea accounted for 5\% - 18\% of the prokaryotic community [35]. Furthermore, in sediments of Lake Taihu the archaeal 16S rDNA in the total prokaryotic community ranged from $14.7 \%$ to $96.9 \%$ [41]. Generally, Archaea are dominant mainly in prokaryotic communities of the deep marine subsurface and saline lake sediments [35] [41] [42] [43] [44].

Based on our results, SS2 displays higher abundances for both bacterial and archaeal communities. Spring is the period of the year where both bacterial and archaeal numbers are lower, whereas the highest abundances are recorded in summer (Table 2).

\subsection{Diversity of the Dominant Bacterial Phylotypes in Lake Pamvotis Sediments}

A total of 153 DGGE bands were identified (Figure S1), processed as described in Methods and found to correspond to 57 unique sequences, most of which are novel. Twenty-nine of these sequences (50.88\%), were found to have $<97 \%$ identity to already deposited Genbank entries. Moreover, 48 of these sequences (84.21\%) were found to have $<97 \%$ identity to already known cultivated bacterial species (Table S1).

Is this bacterial diversity recognizable also with common cultivating techniques? To address this question, R2A plates were inoculated as described in Methods. A total of fifty randomly selected bacterial colonies were grown and characterized further. Of these 50 colonies, 23 different bacterial phylotypes were identified based on $16 \mathrm{~S}$ rDNA sequences. Interestingly, $13.04 \%$ of these sequences, were found to have $<97 \%$ identity to already deposited Genbank entries (Table S2).

Based on the constructed phylogenetic tree (Figures 2(a)-(c)), the DGGE-retrieved sequences (BacPamv; red symbols in Figure 2(a)) revealed that the bacterial community of the sediments in Lake Pamvotis comprised mainly of Proteobacteria $(\beta-, \gamma-, \delta$ - and $\alpha$-Proteobacteria), followed by phylotypes belonging to Cyanobacteria, Nitrospirae, Acidobacteria, Bacteroidetes, Firmicutes, Spirochaetes, Planctomycetes, Actinobacteria, Gemmatimonadetes. We also found six sequences which were not affiliated to any known class and were designated as “unclassified” Bacteria (Unclassified Clusters I, II, and III; Figure 2(a)).

More specifically, most of the DGGE-retrieved Proteobacterial sequences are contained in the class $\beta$-Proteobacteria ( 9 sequences). Four of them have low identity to any known bacterial sequences (<94\%) (Figure 2(a)). This group of Bacteria is often the most abundant in freshwater lakes [45] [46] [47] [48]. In our study, members of $\beta$-Proteobacteria were identified in both stations and during all seasons (Table S3). Concerning the 23 Bacteria isolated in culture from Lake Pamvotis sediments (PamvBac iso; green symbols in Figure 2(a)) six of them were found to be $\beta$-Proteobacteria. Interestingly one $16 \mathrm{~S}$ rDNA sequence corresponding to the cultivated bacterium PamvBac iso.18, displays < 93\% identity to already known 16S rDNA sequences (Table S2). 


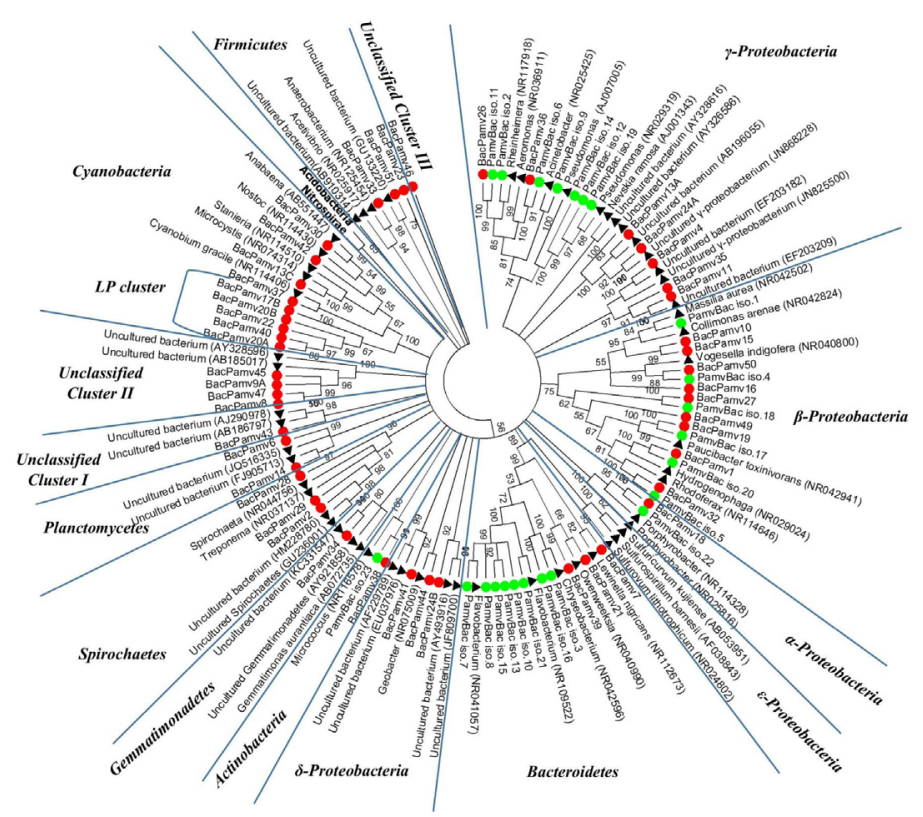

(a)

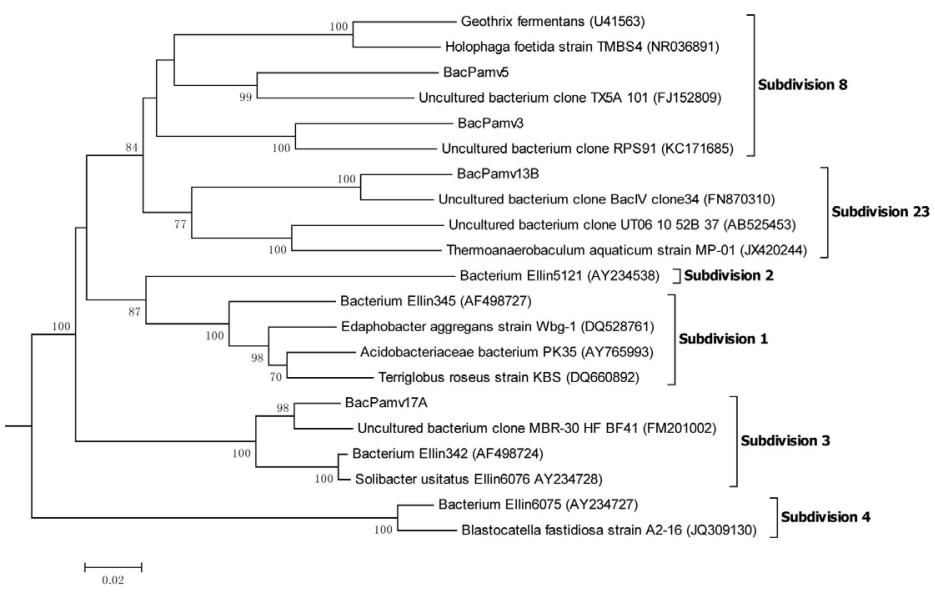

(b)

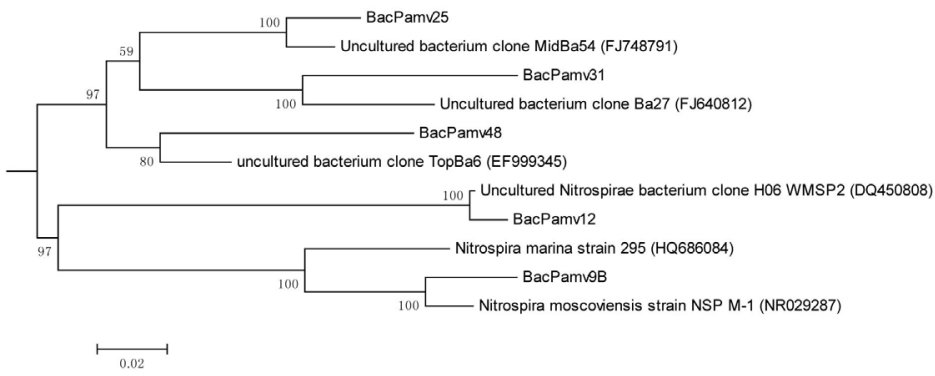

(c)

Figure 2. (a) Distance tree based on the alignment of bacterial $16 \mathrm{~S}$ rDNA sequences from Lake Pamvotis sediments ( BacPamv, PamvBac iso) and ( $\Delta$ ) a number of sequences with the highest similarities retrieved from GenBank/EMBL/DDBJ databases (Branches with bootstrap values below 50\% have been deleted in this presentation); (b) Phylogenetic tree of Acidobacteria-like 16S rDNA sequences (Bootstrap values are shown next to the branches); (c) Phylogenetic tree of Nitrospirae-like 16S rDNA sequences (Bootstrap values are shown next to the branches). 
Cyanobacterial clones were identified in both stations and during all seasons (Table S3). A cyanobacterial clone was strongly related to Microcystis sp. (99\%), a second one to Cyanobium sp. (99\%) and two other sequences were related to Nostocacceae Cyanobacteria although with low identities (92\% - 95\%). The remaining five cyanobacterial clones displayed strikingly low identity percentages $(79 \%$ - 85\%) compared to any other already identified sequence. These "low-identity" sequences might represent either benthic Cyanobacteria or hibernating forms of planktonic Cyanobacteria. It has been shown that lake sediments serve as a storage depot (reservoir) for cyanobacterial cells [49].

In lake Pamvotis, two distinct planktonic cyanobacterial populations had been identified previously, based on internal transcribed spacer (ITS) analysis. One of them was defined as Microcystis sp. and the other one consisted of various filamentous Cyanobacteria which comprise a phylogenetically diverse group unprecedented by other populations worldwide [13]. Based also on ITS data, Cyanobacteria species/strains in two other lakes of the wider area were found to have low identities to other known ITS sequences with the exception of some well characterized cosmopolitan species [12] [50]. These observations led to the notion that the presently unknown species/strains might be endemic in these lakes [50]. It has recently been proposed that in the case of algae (including phytoplankton), the "everything is everywhere" hypothesis should be abandoned since algae are neither cosmopolitan nor ubiquitous [51] [52]. Given that homologies between 16S rDNA sequences are higher than those between ITS, the identification of cyanobacterial 16S rDNA sequences with very low homologies to other existing sequences worldwide strengthens the notion that putatively endemic species are present in Lake Pamvotis. Moreover, the relevant "low-identity" sequences (BacPamv 17B, 20A, 20B, 22, 40) form a robust cluster in the constructed phylogenetic tree (Figure 2(a)), which was designated "LP cluster" (LPC, Lake Pamvotis cluster).

Nitrospirae-like and Acidobacteria-like BacPamv sequences were difficult to be phylogenetically affiliated into the general bacterial phylogenetic tree, mainly due to their low homologies to known Nitrospirae and Acidobacterial sequences (sequence identity 89\% - 96\%) [53]. Therefore, two separate phylogenetic trees were constructed, one for Acidobacteria-like sequences (Figure 2(b)) and one for Nitrospirae-like ones (Figure 2(c)).

Overall, we detected 13 bacterial phyla in Lake Pamvotis sediments. Proteobacteria, Bacteroidetes, Planctomycetes, Actinobacteria, Firmicutes, Acidobacteria and Nitrospirae, have also been observed in other lakes and rivers [54] [55] [56]. The phylum of Proteobacteria was dominant in our sediment samples. This finding is highly reminiscent of the bacterial community structure in other lakes worldwide such as in Lake Taihu and in Lake Geneva [32] [41].

\subsection{Diversity of the Dominant Archaeal Phylotypes in Lake Pamvotis Sediments}

Relative to Bacteria, fewer DGGE bands were identified for Archaea (130 in to- 
tal) but the banding pattern of Archaea was more variable (Figure S2) and a higher number of different archaeal DNA sequences were retrieved (92 in total). A phylogenetic tree of these sequences (ArcPamv, red symbols in Figure 3 ) is presented in Figure 3.

Nineteen of the 92 archaeal sequences (20.65\%) were found to have $<97 \%$ identity to any already known GenBank entry. When comparing with already known cultivated archaeal species, 88 of these sequences (95.65\%) were found to have $<97 \%$ identity to any sequence from cultured Archaea (Table S4). Sequences retrieved were mainly affiliated with Euryarchaeota. Only three of them were classified as Miscellaneous Crenarchaeota (MCG) (Figure 3).

Methanogenic Archaea of the Methanomicrobiales, Methanocellales and Methanosarcinales lineages were predominant in our samples, suggesting that the main archaeal metabolic function in the surface sediment of Lake Pamvotis is methane production. These lineages are frequently observed in the superficial zone of freshwater sediments [41] [57] [58] [59] [60].

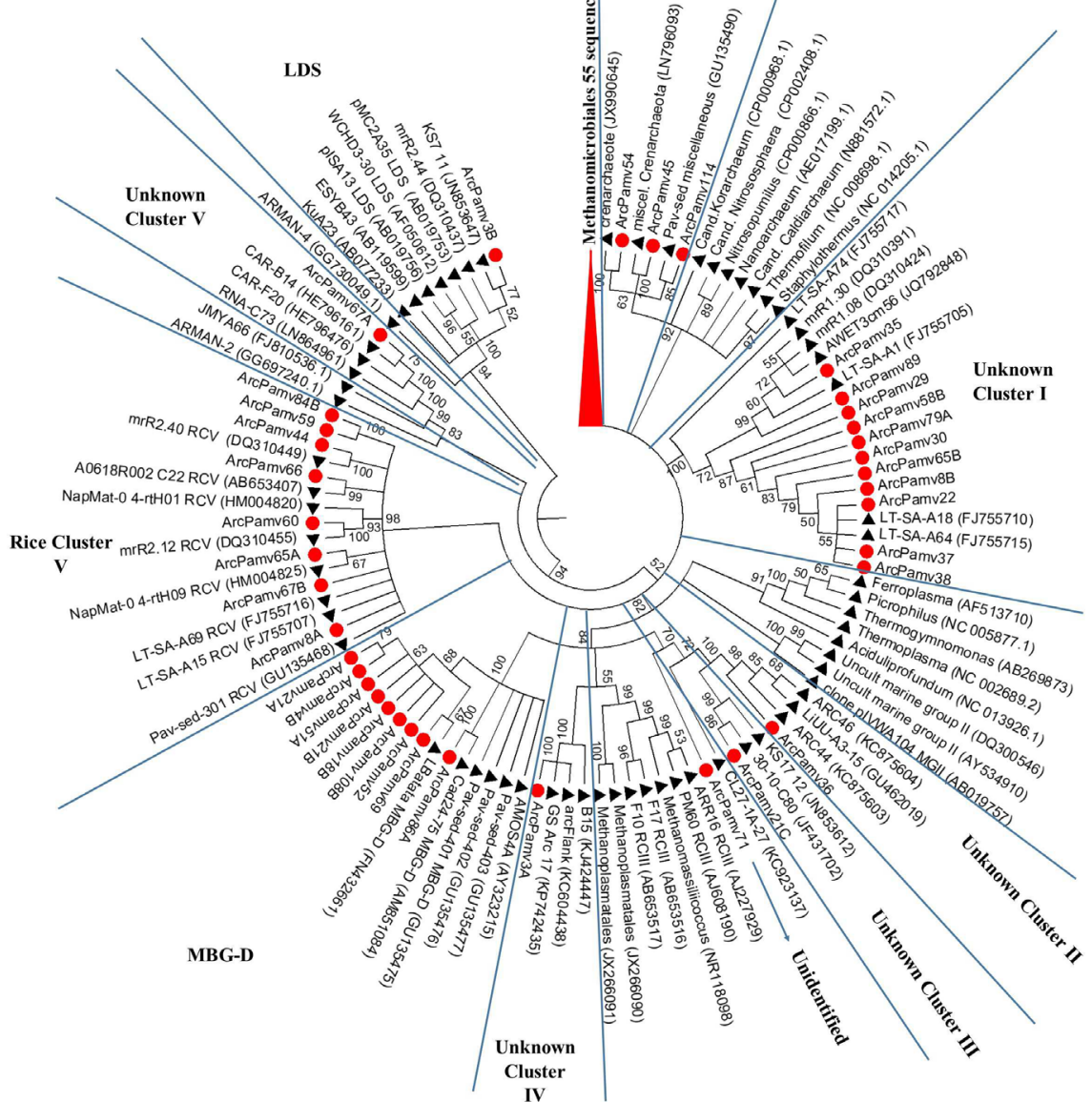

Figure 3. Distance tree based on the alignment of archaeal 16S rDNA sequences from Lake Pamvotis sediments ( ArcPamv) and ( $\bullet$ ) a number of sequences with the highest similarities retrieved from GenBank/EMBL/DDBJ databases (Branches with bootstrap values below $50 \%$ have been deleted in this presentation). 
Uncultured archaeal lineages appear to be ubiquitous in Lake Pamvotis as also observed in other freshwater sediments. Interestingly, we found that the phylogenetic cluster containing the most ArcPamv phylotypes coincides with a previously reported [41] "unknown", "uncharacterized" cluster (Figure 3, "unknown cluster I") (Table S5).

The numbers of ArcPamv sequences belonging to the Marine Benthic Group-D (MBG-D) and Rice Cluster V (RC-V) are comparable to those in the "unknown cluster I". MBG-D represents a highly common fraction of the prokaryotic community in hypersaline sediments and along with RC-V and Lake Dagow Sediment (LDS) lineages represents the most widely distributed uncultured lineages in freshwater sediments [61]. RC-V representatives from Lake Pamvotis form a robust clade with other RC-V sequences retrieved from lake sediments [41], rivers [62] and volcano mats [63] all over the world. Rice cluster V might correspond to non-methanogenic anaerobic Archaea [41] [64]. It has been shown earlier that RC-V and, to a lesser extent, LDS display pronounced genetic diversity and are characterized by long phylogenetic branches [61]. This also holds true for our phylogenetic analysis (Figure 3).

Based on our phylogenetic tree, the LDS cluster was revealed to be more closely related to Candidatus Parvarchaeum acidiphilum (ARMAN-4) [65]. Moreover, the rare "unknown cluster V" was found to be related to Micrarchaeum acidiphilum (ARMAN-2) [64] [66]. Thus, it is tempting to speculate on the physiology and ecology of these clusters, especially for the LDS cluster which is common in freshwater sediments [67] [68].

ARMANS, are nanosized Archaea which have been discovered in chemoautotrophic biofilms of the acidic metal rich Richmond Mine of Iron Mountain California [65]. ARMANS live in association with Thermoplasmatales and contain split genes and high AT contents [65] which are typical of fast evolving symbionts.

Could LDS or the "unknown cluster V" represent acidophilic nanosized symbionts of archaeal lineages related to Thermoplasmatales? This remains to be elucidated. Based on the available 16S rDNA fragments, the representatives of both the LDS and the "unknown cluster V" are characterized by high AT contents comparable to the ones of ARMANS.

The four other Euryarchaeotal rare sequences (ArcPamv36, ArcPamv21C, ArcPamv71 and ArcPamv3A) were found to be related to Thermoplasmatales. Finally, three archaeal sequences (ArcPamv54, ArcPamv45 and ArcPamv114) fall into three robust closely related but distinct clusters with external sequences which have been previously characterized as Miscellaneous Crenarchaeota Group (MCG) [35] [69]. In our phylogenetic analysis these MCG clusters were found to be more closely related to Korarchaeotal Thaumarchaeota. This is in accordance with previously published studies emphasizing that the affiliation of MCG and MBG-B within the Crenarchaeota is debated and proposing an alternative phylogenetic relationship either to Thaumarchaeota or to the Aigarchaea [70] [71]. 
In any case, MCG is a cosmopolitan group, frequently identified in anoxic habitants [42] [72]. Members of the MCG cluster are considered as heterotrophic anaerobes [73] and suggestively, they may obtain energy from the anaerobic oxidation of methane [73] in buried sediments. MCGs were found to be predominant in the intermediate layers of Lake Pavin sediments and their abundance was correlated with the decrease of methane concentrations in these layers [35]. In our study, the low number of MCG sequences retrieved could be attributed to the use of surface sediments only.

\subsection{Relations between Physicochemical Variables, Prokaryotic Abundances and Diversity of the Dominant Prokaryotic Phylotypes}

Regarding nutrient loads, TN was positively correlated with bacterial and, to a lesser extent, with archaeal abundances, whereas TOC was found to affect mainly the archaeal abundances (Table 3 ). These findings suggest that Bacteria are

Table 3. Results of correlation analysis between physicochemical and biological variables.

\begin{tabular}{|c|c|c|}
\hline & Bacteria & Archaea \\
\hline Depth & 0.29 & 0.34 \\
\hline $\mathrm{T}$ & -0.34 & 0.07 \\
\hline $\mathrm{pH}$ & -0.57 & -0.85 \\
\hline $\mathrm{TC}$ & 0.12 & 0.55 \\
\hline TOC & 0.27 & 0.65 \\
\hline $\mathrm{TP}$ & 0.44 & 0.01 \\
\hline $\mathrm{TN}$ & 0.61 & 0.54 \\
\hline $\mathrm{Na}$ & -0.02 & 0.39 \\
\hline K & 0.56 & 0.54 \\
\hline $\mathrm{Ca}$ & 0.58 & 0.75 \\
\hline $\mathrm{Mg}$ & 0.54 & 0.64 \\
\hline $\mathrm{Cl}$ & 0.16 & 0.59 \\
\hline $\mathrm{SO}_{4}$ & 0.46 & 0.43 \\
\hline $\mathrm{Sb}$ & -0.53 & -0.61 \\
\hline $\mathrm{Ni}$ & -0.69 & -0.91 \\
\hline $\mathrm{Hg}$ & -0.32 & 0.07 \\
\hline $\mathrm{Mn}$ & -0.02 & -0.08 \\
\hline $\mathrm{Fe}$ & -0.46 & -0.52 \\
\hline $\mathrm{Cu}$ & 0.40 & 0.19 \\
\hline $\mathrm{Cr}$ & -0.66 & -0.81 \\
\hline $\mathrm{Zn}$ & 0.20 & 0.09 \\
\hline As & 0.55 & 0.8 \\
\hline
\end{tabular}

Results of correlation analysis between physicochemical variables and bacterial/archaeal abundances. Spearman's correlation coefficients are shown. Statistically significant correlations are indicated in yellow $(\mathrm{p}<0.05)$ or in red $(\mathrm{p}<0.001)$. 
the major players in the recycling of nitrogen and Archaea might be more important for carbon mineralization. In SS2, which is more heavily loaded with TC and TOC, methanogenic phylotypes are more common than in SS1 (Table S5). In any case, key functional genes, of both bacterial and archaeal origin, involved in nitrogen and carbon metabolism need to be studied in order to address this hypothesis more rigorously [74] [75].

Calcium concentration levels were correlated positively with both bacterial and archaeal cell numbers, suggesting a possible adaptation of the prokaryotic populations to a calcareous environment. Such an environment has been established in the sediments of the lake from ancient years, since the surrounding mountains consist mainly of lime bedrocks.

Concerning heavy metals, As had a strong positive effect on archaeal and a mild positive effect on bacterial cell abundances. In contrast, $\mathrm{Ni}$ and $\mathrm{Cr}$ seem to affect negatively both bacterial and archaeal abundances and, again, the effect is stronger on Archaea. Given that genes for metabolism, resistance and detoxification of metals are widespread throughout the archaeal and the bacterial domains [76] [77] [78] the contrasting effects of As and $\mathrm{Ni}$ or Cr on prokaryotic abundances in Lake Pamvotis are puzzling. One possible explanation for the positive effect of As is probably the time of exposure. It seems likely that the prokaryotic populations have coped with As for a longer time period compared to $\mathrm{Ni}$ and $\mathrm{Cr}$ and this has leaded to an adaptation of both Bacteria and Archaea to As contamination. Indeed, this should have been the case at least for $\mathrm{Ni}$, since high $\mathrm{Ni}$ concentrations have been measured only during the last ten years. Moreover, it is of interest that $\mathrm{Ni}$ exceeds PEC in the sediments of the Lake and $\mathrm{Cr}$ exceeds TEC during all seasons, whereas As does not exceed either PEC or TEC (Table 1). The higher amounts of both $\mathrm{Ni}$ and $\mathrm{Cr}$ in SS1 might explain the lower abundances of both Bacteria and Archaea in this station compared to SS2.

In our study, $\mathrm{pH}$ was found to affect negatively the abundances of both Archaea and Bacteria, but the most significant effect was found for Archaea (Table 3).

Soil $\mathrm{pH}$ affects the chemical form, concentration and availability of different substrates [79]. The $\mathrm{pH}$ affects also methanogenesis. At slightly acidic conditions ( $\mathrm{pH}$ 6.5) acetoclastic methanogenesis is inhibited. In contrast hydrogenotrophic methanogenesis is affected only slightly (0.03\% compared to control $\mathrm{pH} 7.0)$ [80]. Given that most of the archaeal phylotypes isolated in our study are related to Methanogens, the higher abundances of Archaea in the station with the lower $\mathrm{pH}$ could be attributed to the prevalence of hydrogenotrophic methanogens in this station. Interestingly, most of the sequences related to Methanoregula boonei [81], an exclusively hydrogenotrophic archaeon were isolated from SS2. Based also on our results (Table S5), representatives of RC-V are more abundant in SS2 than in SS1 and since RC-V are thought not to be methanogenic, we may conclude that there is not a simple negative relationship between $\mathrm{pH}$ and the abundance of sedimental archaeal communities. 
Concerning diversity, there are no obvious differences between the two sample stations with respect to the dominant bacterial phylotypes (Table S3). In contrast, with respect to Archaea, the numbers of different methanogenic and RC-V representatives are higher in SS2 than in SS1 (Table S5). Overall, the archaeal diversity in Lake Pamvotis sediments appears to be higher than the bacterial diversity at least for the dominant phylotypes.

From the relatively limited available literature, numerical differences between bacterial and archaeal diversities in lake sediments remain unclear. Some previously published studies indicate a higher bacterial over archaeal diversity in lake sediments [41] [82] while others point to a higher diversity of Archaea [83] [84]. In view of our current evidence, traditional techniques combined with next-generation sequencing technology can theoretically illustrate the overall diversity [85] [86] [87] and such studies should be important for an in-depth analysis of the community structure in the sediments of Lake Pamvotis.

A number of environmental factors such as $\mathrm{pH}$ [88], and heavy metals [89] were recognized as important determinants of prokaryotic community structure in previous studies. Given that there are differences in the determined environmental parameters between the two sampling stations in Lake Pamvotis, the essentially equal numbers of different bacterial sequences in the two stations suggest that the bacterial community diversity is not sensitive to these environmental factors. In contrast, the archaeal diversity was clearly greater in SS2 (Table $\mathrm{S} 5)$. Lower $\mathrm{pH}$ values, lower concentrations of $\mathrm{Ni}$ and $\mathrm{Cr}$ along with higher $\mathrm{As}$ and TC concentrations are the main environmental factors differentiating SS2 from SS1; these factors are potential determinants of the archaeal diversity. Significant decrease in microbial diversity due to metal contamination was shown previously for Archaea in other lake sediments [33]. Moreover, in high As shallow aquifers, the increase of As concentrations apparently shifts the dominant archaeal populations from Thaumarchaeota to Euryarchaeota (mainly methanogens) [90]. Based on the literature and our data, we postulate that the decreased archaeal diversity in SS1 compared to SS2 could be attributed to the presence of higher amounts of $\mathrm{Ni}$ and $\mathrm{Cr}$ in this station. Consequently, it seems likely that a combination of the higher amounts of As and TC and the lower $\mathrm{pH}$ values in SS2 (Table 1) could be responsible for the higher diversity of both Methanogens and RC-V representatives in this station.

\section{Conclusions}

To our knowledge, this is the first study on both bacterial and archaeal abundances, diversity and community structure in the sediments of an ancient lake within the major European freshwater biodiversity hotspot.

$\mathrm{Ni}$ and $\mathrm{Cr}$ affect negatively both bacterial and archaeal abundances while $\mathrm{Ca}$ concentrations were found to have a positive effect. $\mathrm{pH}$ affects negatively mainly the archaeal abundance. TN has a strong positive effect on bacterial abundance, whereas As and TOC affect mainly Archaea. 
Based on molecular characterization of the microbial communities, several new prokaryotic species were identified. A new class of Cyanobacteria was discovered in Lake Pamvotis sediments and termed "Lake Pamvotis cluster" (LPC). Concerning Archaea, most of the sequences retrieved from the sediments were affiliated to Euryarchaeota (dominated by Methanogenic Archaea). Interestingly, the widespread uncultivated cluster LDS was found to be phylogenetically related to ARMAN-4 lineage suggesting an unprecedented ecological role for this cluster.

\section{Acknowledgements}

We would like to acknowledge the late professor Evangelos Briasoulis for his critical reading of the paper, his valuable corrections and helpful discussion. We would like to acknowledge Mr. Sotiris Simos for his help during sampling in Lake Pamvotis.

\section{Conflicts of Interest}

The authors declare no conflict of interest.

\section{References}

[1] Wilson, A.B., Glaubrecht, M. and Meyer, A. (2004) Ancient Lakes as Evolutionary Reservoirs: Evidence from the Thalassoid Gastropods of Lake Tanganyika. Proceedings of the Royal Society B: Biological Sciences, 271, 529-536. https://doi.org/10.1098/rspb.2003.2624

[2] Wagner, B. and Wilke, T. (2011) Preface "Evoltionary and Geological History of the Balkan Lakes Ohrid and Prespa”. Biogeosciences, 8, 995-998. https://doi.org/10.5194/bg-8-995-2011

[3] Sherbakov, D.Y. (1999) Molecular Phylogenetic Studies on the Origin of Biodiversity in Lake Baikal. Trends in Ecology \& Evolution, 14, 92-95. https://doi.org/10.1016/S0169-5347(98)01543-2

[4] Frogley, M.R., Griffiths, H.I. and Heaton, T.H.E. (2001) Historical Biogeography and Late Quaternary Environmental Change of Lake Pamvotis, Ioannina (North-Western Greece): Evidence from Ostracods. Journal of Biogeography, 28, 745-756. https://doi.org/10.1046/j.1365-2699.2001.00582.x

[5] Albrecht, C. and Wilke, T. (2008) Ancient Lake Ohrid: Biodiversity and Evolution. Hydrobiologia, 615, 103-140. https://doi.org/10.1007/s10750-008-9558-y

[6] Stankovic, S. (1960) The Balkan Lake Ohrid and Its Living World. Monographiae Biologicae, IX, Dr. W. Junk Publishers, The Hague.

[7] Vogel, H., Wessels, M., Albrecht, C., Stich, H.B. and Wagner, B. (2010) Spatial Variability of Recent Sedimentation in Lake Ohrid (Albania/Macedonia). Biogeosciences, 7, 3333-3342. https://doi.org/10.5194/bg-7-3333-2010

[8] Griffiths, H.I., Reed, J.M., Leng, M.J., Ryan, S. and Petkovski, S. (2002) The Recent Palaeoecology and Conservation Status of Balkan Lake Dojran. Biological Conservation, 104, 35-49. https://doi.org/10.1016/S0006-3207(01)00152-5

[9] Albrecht, C., Hauffe, T., Schreiber, K., Trajanovski, S. and Wilke, T. (2009) Mollusc Biodiversity and Endemism in the Potential Ancient Lake Trichonis, Greece. Malacologia, 51, 357-375. https://doi.org/10.4002/040.051.0209 
[10] Frogley, M.R. and Preece, R.C. (2007) A Review of the Aquatic Mollusca from Lake Pamvotis, Ioannina, an Ancient Lake in NW Greece. Journal of Conchology, 39, 271-296.

[11] Tzedakis, P.C., Lawson, I.T., Frogley, M.R., Hewitt, G.M. and Preece, R.C. (2002) Buffered Tree Population Changes in a Quaternary Refugium: Evolutionary Implications. Science, 297, 2044-2047. https://doi.org/10.1126/science.1073083

[12] Vareli, K., Briasoulis, E., Pilidis, G. and Sainis, I. (2009) Molecular Confirmation of Planktothrix rubescens as the Cause of Intense, Microcystin-Synthesizing Cyanobacterial Bloom in Lake Ziros, Greece. Harmful Algae, 8, 447-453. https://doi.org/10.1016/j.hal.2008.09.005

[13] Vareli, K., Pilidis, G., Mavrogiorgou, M.C., Briasoulis, E. and Sainis, I. (2009) Molecular Characterization of Cyanobacterial Diversity and Yearly Fluctuations of Microcystin Loads in a Suburban Mediterranean Lake (Lake Pamvotis, Greece). Journal of Environmental Monitoring, 11, 1506-1512. https://doi.org/10.1039/b903093j

[14] Kormas, K.A., Gkelis, S., Vardaka, E. and Moustaka-Gouni, M. (2011) Morphological and Molecular Analysis of Bloom-forming Cyanobacteria in two Eutrophic, Shallow Mediterranean Lakes. Limnologica-Ecology and Management of Inland Waters, 41, 167-173. https://doi.org/10.1016/j.limno.2010.10.003

[15] Kormas, K.A., Vardaka, E., Moustaka-Gouni, M., Kontoyanni, V., Petridou, E., Gkelis, S., et al. (2010) Molecular Detection of Potentially Toxic Cyanobacteria and their Associated Bacteria in Lake Water Column and Sediment. World Journal of Microbiology and Biotechnology, 26, 1473-1482. https://doi.org/10.1007/s11274-010-0322-x

[16] Gkelis, S., Rajaniemi, P., Vardaka, E., Moustaka-Gouni, M., Lanaras, T. and Sivonen, K. (2005) Limnothrix redekei (Van Goor) Meffert (Cyanobacteria) Strains from Lake Kastoria, Greece form a Separate Phylogenetic Group. Microbial Ecology, 49, 176-182. https://doi.org/10.1007/s00248-003-2030-7

[17] Fotyma, M., Jadczyszyn, T. and Jozefaciuk, G. (1998) Hundredth Molar Calcium Chloride Extraction Procedure. Part II: Calibration with Conventional Soil Testing Methods for pH. Communications in Soil Science and Plant Analysis, 29, 1625-1632. https://doi.org/10.1080/00103629809370054

[18] Jackson, P.E. (2006) Ion Chromatography in Environmental Analysis. Encyclopedia of Analytical Chemistry, John Wiley \& Sons Ltd., Chichester.

[19] Kotti, M.E., Vlessidis, A.G. and Evmiridis, N.P. (2000) Determination of Phosphorous and Nitrogen in the Sediment of Lake "Pamvotis" (Greece). International Journal of Environmental Analytical Chemistry, 78, 455-467. https://doi.org/10.1080/03067310008041360

[20] Ashley, K., Andrews, R.N., Cavazos, L. and Demange, M. (2001) Ultrasonic Extraction as a Sample Preparation Technique for Elemental Analysis by Atomic Spectrometry. Journal of Analytical Atomic Spectrometry, 16, 1147-1153. https://doi.org/10.1039/b102027g

[21] Tamaki, H., Sekiguchi, Y., Hanada, S., Nakamura, K., Nomura, N., Matsumura, M., et al. (2005) Comparative Analysis of Bacterial Diversity in Freshwater Sediment of a Shallow Eutrophic Lake by Molecular and Improved Cultivation-Based Techniques. Applied and Environmental Microbiology, 71, 2162-2169. https://doi.org/10.1128/AEM.71.4.2162-2169.2005

[22] Berg, K.A., Lyra, C., Sivonen, K., Paulin, L., Suomalainen, S., Tuomi, P., et al. (2009) High Diversity of Cultivable Heterotrophic Bacteria in Association with Cyanobacterial Water Blooms. The ISME Journal, 3, 314-325. 
https://doi.org/10.1038/ismej.2008.110

[23] Casamayor, E.O., Schafer, H., Baneras, L., Pedros-Alio, C. and Muyzer, G. (2000) Identification of and Spatio-Temporal Differences between Microbial Assemblages from Two Neighboring Sulfurous Lakes: Comparison by Microscopy and Denaturing Gradient Gel Electrophoresis. Applied and Environmental Microbiology, 66, 499-508. https://doi.org/10.1128/AEM.66.2.499-508.2000

[24] Muyzer, G., Teske, A., Wirsen, C.O. and Jannasch, H.W. (1995) Phylogenetic Relationships of Thiomicrospira Species and Their Identification in Deep-Sea Hydrothermal Vent Samples by Denaturing Gradient Gel Electrophoresis of 16S rDNA Fragments. Archives of Microbiology, 164, 165-172.

https://doi.org/10.1007/BF02529967

[25] Klappenbach, J.A., Dunbar, J.M. and Schmidt, T.M. (2000) rRNA Operon Copy Number Reflects Ecological Strategies of Bacteria. Applied and Environmental Microbiology, 66, 1328-1333. https://doi.org/10.1128/AEM.66.4.1328-1333.2000

[26] Muyzer, G., de Waal, E.C. and Uitterlinden, A.G. (1993) Profiling of Complex Microbial Populations by Denaturing Gradient Gel Electrophoresis Analysis of Polymerase Chain Reaction-Amplified Genes Coding for 16S rRNA. Applied and Environmental Microbiology, 59, 695-700

[27] Janse, I., Meima, M., Kardinaal, W.E. and Zwart, G. (2003) High-Resolution Differentiation of Cyanobacteria by using rRNA-Internal Transcribed Spacer Denaturing Gradient Gel Electrophoresis. Applied and Environmental Microbiology, 69, 6634-6643. https://doi.org/10.1128/AEM.69.11.6634-6643.2003

[28] Vokou, D., Vareli, K., Zarali, E., Karamanoli, K., Constantinidou, H.I., Monokrousos, N., et al. (2012) Exploring Biodiversity in the Bacterial Community of the Mediterranean Phyllosphere and Its Relationship with Airborne Bacteria. Microbial Ecology, 64,714-724. https://doi.org/10.1007/s00248-012-0053-7

[29] Tamura, K., Peterson, D., Peterson, N., Stecher, G., Nei, M. and Kumar, S. (2011) Mega5: Molecular Evolutionary Genetics Analysis Using Maximum Likelihood, Evolutionary Distance, and Maximum Parsimony Methods. Molecular Biology and Evolution, 28, 2731-2739. https://doi.org/10.1093/molbev/msr121

[30] Romero, J.R., Kagalou, I., Imberger, J., Hela, D., Kotti, M., Bartzokas, A., et al. (2002) Seasonal Water Quality of Shallow and Eutrophic Lake Pamvotis, Greece: Implications for Restoration. Hydrobiologia, 474, 91-105.

https://doi.org/10.1023/A:1016569124312

[31] Daskalou, V., Vreca, P., Muri, G. and Stalikas, C. (2009) Recent Environmental Changes in the Shallow Lake Pamvotis (NW Greece): Evidence from Sedimentary Organic Matter, Hydrocarbons, and Stable Isotopes. Archives of Environmental Contamination and Toxicology, 57, 21-31. https://doi.org/10.1007/s00244-008-9246-y

[32] Haller, L., Tonolla, M., Zopfi, J., Peduzzi, R., Wildi, W. and Pote, J. (2011) Composition of Bacterial and Archaeal Communities in Freshwater Sediments with Different Contamination Levels (Lake Geneva, Switzerland). Water Research, 45, 1213-1228. https://doi.org/10.1016/j.watres.2010.11.018

[33] Gough, H.L. and Stahl, D.A. (2011) Microbial Community Structures in Anoxic Freshwater Lake Sediment along a Metal Contamination Gradient. The ISME Journal, 5, 543-558. https://doi.org/10.1038/ismej.2010.132

[34] Bhattarai, S., Ross, K.A., Schmid, M., Anselmetti, F.S. and Burgmann, H. (2012) Local Conditions Structure Unique Archaeal Communities in the Anoxic Sediments of Meromictic Lake Kivu. Microbial Ecology, 64, 291-310. 
https://doi.org/10.1007/s00248-012-0034-x

[35] Borrel, G., Lehours, A.C., Crouzet, O., Jezequel, D., Rockne, K., Kulczak, A., et al. (2012) Stratification of Archaea in the Deep Sediments of a Freshwater Meromictic Lake: Vertical Shift from Methanogenic to Uncultured Archaeal Lineages. PLoS ONE, 7, e43346. https://doi.org/10.1371/journal.pone.0043346

[36] MacDonald, D.D., Ingersoll, C.G. and Berger, T.A. (2000) Development and Evaluation of Consensus-Based Sediment Quality Quidelines for Freshwater Ecosystems. Archives of Environmental Contamination and Toxicology, 39, 20-31. https://doi.org/10.1007/s002440010075

[37] Stalikas, C., Pilidis, G. and Karayannis, M. (1994) Heavy Metal Contents in Sediments of the Lake Ioannina and Kalamas River in North-Western Greece. Fresenius Environmental Bulletin, 3, 575-579.

[38] Watzin, M.C, Puka, V. and Naumoski, T.B. (2002) Lake Ohrid and Its Watershed, State of the Environment Report. Lake Ohrid Conservation Project, Tirana, Ohrid.

[39] Skoulikidis, N.T. (2008) Defining Chemical Status of a Temporary Mediterranean River. Journal of Environmental Monitoring, 10, 842-852. https://doi.org/10.1039/b800768c

[40] Ioannides, K., Stamoulis, K., Papachristodoulou, C., Tziamou, E., Markantonaki, C. and Tsodoulos, I. (2015) Distribution of Heavy Metals in Sediment Cores of Lake Pamvotis (Greece): A Pollution and Potential Risk Assessment. Environmental Monitoring and Assessment, 187, 4209. https://doi.org/10.1007/s10661-014-4209-4

[41] Ye, W., Liu, X., Lin, S., Tan, J., Pan, J., Li, D., et al. (2009) The Vertical Distribution of Bacterial and Archaeal Communities in the Water and Sediment of Lake Taihu. FEMS Microbiology Ecology, 70, 107-120. https://doi.org/10.1111/j.1574-6941.2009.00761.x

[42] Teske, A. and Sorensen, K.B. (2008) Uncultured Archaea in Deep Marine Subsurface Sediments: Have We Caught Them All? The ISME Journal, 2, 3-18. https://doi.org/10.1038/ismej.2007.90

[43] Lipp, J.S., Morono, Y., Inagaki, F. and Hinrichs, K.U. (2008) Significant Contribution of Archaea to Extant Biomass in Marine Subsurface Sediments. Nature, 454, 991-994. https://doi.org/10.1038/nature07174

[44] Jiang, H., Dong, H., Yu, B., Ye, Q., Shen, J., Rowe, H., et al. (2008) Dominance of Putative Marine Benthic Archaea in Qinghai Lake, North-Western China. Environmental Microbiology, 10, 2355-2367. https://doi.org/10.1111/j.1462-2920.2008.01661.x

[45] Buck, U., Grossart, H.P., Amann, R. and Pernthaler, J. (2009) Substrate Incorporation Patterns of Bacterioplankton Populations in Stratified and Mixed Waters of a Humic Lake. Environmental Microbiology, 11, 1854-1865. https://doi.org/10.1111/j.1462-2920.2009.01910.x

[46] Glockner, F.O., Zaichikov, E., Belkova, N., Denissova, L., Pernthaler, J., Pernthaler, A., et al. (2000) Comparative 16S rRNA analysis of Lake Bacterioplankton Reveals Globally Distributed Phylogenetic Clusters Including an Abundant Group of Actinobacteria. Applied and Environmental Microbiology, 66, 5053-5065. https://doi.org/10.1128/AEM.66.11.5053-5065.2000

[47] Hiorns, W.D., Methe, B.A., Nierzwicki-Bauer, S.A. and Zehr, J.P. (1997) Bacterial Diversity in Adirondack Mountain Lakes as Revealed by 16S rRNA Gene Sequences. Applied and Environmental Microbiology, 63, 2957-2960.

[48] Zwisler, W., Selje, N. and Simon, M. (2003) Seasonal Patterns of the Bacterioplankton Community Composition in a Large Mesotrophic Lake. Aquatic Microbial 
Ecology, 31, 211-225. https://doi.org/10.3354/ame031211

[49] Rinta-Kanto, J.M., Saxton, M.A., DeBruyn, J.M., Smith, J.L., Marvin, C.H., Krieger, K.A., et al. (2009) The Diversity and Distribution of Toxigenic Microcystis spp. in Present Day and Archived Pelagic and Sediment Samples from Lake Erie. Harmful Algae, 8, 385-394. https://doi.org/10.1016/j.hal.2008.08.026

[50] Vareli, K., Touka, A., Theurillat, X., Briasoulis, E., Pilidis, G. and Sainis, I. (2015) Microcystins in Two Low Nutrient Lakes in the Epirus Region of North-West Greece. CLEAN-Soil, Air, Water, 43, 1307-1315. https://doi.org/10.1002/clen.201400482

[51] Incagnone, G., Marrone, F., Barone, R., Robba, L. and Naselli-Flores, L. (2014) How do Freshwater Organisms Cross the "Dry Ocean"? A Review on Passive Dispersal and Colonization Processes with a Special Focus on Temporary Ponds. Hydrobiologia, 750, 103-123. https://doi.org/10.1007/s10750-014-2110-3

[52] Padisák, J., Vasas, G. and Borics, G. (2015) Phycogeography of Freshwater Phytoplankton: Traditional Knowledge and New Molecular Tools. Hydrobiologia, 764, 3-27. https://doi.org/10.1007/s10750-015-2259-4

[53] Costello, E.K. and Schmidt, S.K. (2006) Microbial Diversity in Alpine Tundra Wet Meadow Soil: Novel Chloroflexi from a Cold, Water-Saturated Environment. Environmental Microbiology, 8, 1471-1486. https://doi.org/10.1111/j.1462-2920.2006.01041.x

[54] Liu, F.H., Lin, G.H., Gao, G., Qin, B.Q., Zhang, J.S., Zhao, G.P., et al. (2009) Bacterial and Archaeal Assemblages in Sediments of a Large Shallow Freshwater Lake, Lake Taihu, as Revealed by Denaturing Gradient Gel Electrophoresis. Journal of Applied Microbiology, 106, 1022-1032. https://doi.org/10.1111/j.1365-2672.2008.04069.x

[55] Zwart, G., Crump, B.C., Kamst-van Agterveld, M.P., Hagen, F. and Han, S-K. (2002) Typical Freshwater Bacteria: An Analysis of Available 16S rRNA Gene Sequences from Plankton of Lakes and Rivers. Aquatic Microbial Ecology, 28, 141-155. https://doi.org/10.3354/ame028141

[56] Eiler, A. and Bertilsson, S. (2004) Composition of Freshwater Bacterial Communities Associated with Cyanobacterial Blooms in Four Swedish Lakes. Environmental Microbiology, 6, 1228-1243. https://doi.org/10.1111/j.1462-2920.2004.00657.x

[57] Schwarz, J.I., Eckert, W. and Conrad, R. (2007) Community Structure of Archaea and Bacteria in a Profundal Lake Sediment Lake Kinneret (Israel). Systematic and Applied Microbiology, 30, 239-254. https://doi.org/10.1016/j.syapm.2006.05.004

[58] Chan, O.C., Claus, P., Casper, P., Ulrich, A., Lueders, T. and Conrad, R. (2005) Vertical Distribution of Structure and Function of the Methanogenic Archaeal Community in Lake Dagow Sediment. Environmental Microbiology, 7, 1139-1149. https://doi.org/10.1111/j.1462-2920.2005.00790.x

[59] Koizumi, Y., Takii, S. and Fukui, M. (2004) Depth-related Change in Archaeal Community Structure in a Freshwater Lake Sediment as Determined with Denaturing Gradient Gel Electrophoresis of Amplified 16S rRNA Genes and Reversely Transcribed rRNA Fragments. FEMS Microbiology Ecology, 48, 285-292. https://doi.org/10.1016/j.femsec.2004.02.013

[60] Glissman, K., Chin, K.J., Casper, P. and Conrad, R. (2004) Methanogenic Pathway and Archaeal Community Structure in the Sediment of Eutrophic Lake Dagow: Effect of Temperature. Microbial Ecology, 48, 389-399. https://doi.org/10.1007/s00248-003-2027-2

[61] Barberan, A., Fernandez-Guerra, A., Auguet, J.C., Galand, P.E. and Casamayor, 
E.O. (2011) Phylogenetic Ecology of Widespread Uncultured Clades of the Kingdom Euryarchaeota. Molecular Ecology, 20, 1988-1996. https://doi.org/10.1111/j.1365-294X.2011.05057.x

[62] Pierre, E.G., Connie, L. and Warwick, F.V. (2006) Remarkably Diverse and Contrasting Archaeal Communities in a Large Arctic River and the Coastal Arctic Ocean. Aquatic Microbial Ecology, 44, 115-126. https://doi.org/10.3354/ame044115

[63] Lazar, C.S., L'Haridon, S., Pignet, P. and Toffin, L. (2011) Archaeal Populations in Hypersaline Sediments Underlying Orange Microbial Mats in the Napoli Mud Volcano. Applied and Environmental Microbiology, 77, 3120-3131. https://doi.org/10.1128/AEM.01296-10

[64] Grokopf, R., Stubner, S. and Liesack, W. (1998) Novel Euryarchaeotal Lineages Detected on Rice Roots and in the Anoxic Bulk Soil of Flooded Rice Microcosms. Applied and Environmental Microbiology, 64, 4983-4989.

[65] Baker, B.J., Comolli, L.R., Dick, G.J., Hauser, L.J., Hyatt, D., Dill, B.D., et al. (2010) Enigmatic, Ultrasmall, Uncultivated Archaea. PNAS, 107, 8806-8811.

https://doi.org/10.1073/pnas.0914470107

[66] Dick, G.J., Andersson, A.F., Baker, B.J., Simmons, S.L., Thomas, B.C., Yelton, A.P., et al. (2009) Community-Wide Analysis of Microbial Genome Sequence Signatures. Genome Biology, 10, R85. https://doi.org/10.1186/gb-2009-10-8-r85

[67] Rudiger, O.A. and Casamayor, O.E. (2016) High Occurrence of Pacearchaeota and Woesearchaeota (Archaea Superphylum DPANN) in the Surface Waters of Oligotrophic High-Altitude Lakes. Environmental Microbiology Reports, 8, 210-217. https://doi.org/10.1111/1758-2229.12370

[68] Castelle, C.J., Wrighton, K.C., Thomas, B.C., Hug, L.A., Brown, C.T., Wilkins, M.J., et al. (2015) Genomic Expansion of Domain Archaea Highlights Roles for Organisms from New Phyla in Anaerobic Carbon Cycling. Current Biology, 25, 690-701. https://doi.org/10.1016/j.cub.2015.01.014

[69] Buckles, L.K., Villanueva, L., Weijers, J.W., Verschuren, D. and Damste, J.S. (2013) Linking Isoprenoidal GDGT Membrane Lipid Distributions with Gene Abundances of Ammonia-Oxidizing Thaumarchaeota and Uncultured Crenarchaeotal Groups in the Water Column of a Tropical Lake (Lake Challa, East Africa). Environmental Microbiology, 15, 2445-2462. https://doi.org/10.1111/1462-2920.12118

[70] Pester, M., Schleper, C. and Wagner, M. (2011) The Thaumarchaeota: An Emerging View of Their Phylogeny and Ecophysiology. Current Opinion in Microbiology, 14, 300-306. https://doi.org/10.1016/j.mib.2011.04.007

[71] Brochier-Armanet, C., Boussau, B., Gribaldo, S. and Forterre, P. (2008) Mesophilic Crenarchaeota: Proposal for a Third Archaeal Phylum, the Thaumarchaeota. Nature Reviews Microbiology, 6, 245-252. https://doi.org/10.1038/nrmicro1852

[72] Takano, Y., Chikaraishi, Y., Ogawa, N.O., Nomaki, H., Morono, Y., Inagaki, F., et al. (2010) Sedimentary Membrane Lipids Recycled by Deep-Sea Benthic Archaea. Nature Geoscience, 3, 858-861. https://doi.org/10.1038/ngeo983

[73] Biddle, J.F., Lipp, J.S., Lever, M.A., Lloyd, K.G., Sorensen, K.B., Anderson, R., et al. (2006) Heterotrophic Archaea Dominate Sedimentary Subsurface Ecosystems of Peru. PNAS, 103, 3846-3851. https://doi.org/10.1073/pnas.0600035103

[74] Yin, H., Niu, J., Ren, Y., Cong, J., Zhang, X., Fan, F., et al. (2015) An Integrated Insight into the Response of Sedimentary Microbial Communities to Heavy Metal Contamination. Scientific Reports, 5, Article No. 14266. https://doi.org/10.1038/srep14266

[75] Jung, J., Yeom, J., Han, J., Kim, J. and Park, W. (2012) Seasonal Changes in Nitro- 
gen-Cycle Gene Abundances and in Bacterial Communities in Acidic Forest Soils. Journal of Microbiology, 50, 365-373. https://doi.org/10.1007/s12275-012-1465-2

[76] Bini, E. (2010) Archaeal Transformation of Metals in the Environment. FEMS Microbiology Ecology, 73, 1-16. https://doi.org/10.1111/j.1574-6941.2010.00876.x

[77] Burkhardt, E.M., Bischoff, S., Akob, D.M., Büchel, G. and Küsel, K. (2011) Heavy Metal Tolerance of Fe(III)-Reducing Microbial Communities in Contaminated Creek Bank Soils. Applied and Environmental Microbiology, 77, 3132-3136. https://doi.org/10.1128/AEM.02085-10

[78] Gupta, K., Chatterjee, C. and Gupta, B. (2012) Isolation and Characterization of Heavy Metal Tolerant Gram-Positive Bacteria with Bioremedial Properties from Municipal Waste Rich Soil of Kestopur Canal (Kolkata), West Bengal, India. Biologia, 67, 827-836. https://doi.org/10.2478/s11756-012-0099-5

[79] Kemmitt, S.J., Wright, D., Goulding, K.W.T. and Jones, D.L. (2006) pH Regulation of Carbon and Nitrogen Dynamics in Two Agricultural Soils. Soil Biology and Biochemistry, 38, 898-911. https://doi.org/10.1016/j.soilbio.2005.08.006

[80] Ban, Q., Li, J., Zhang, L., Zhang, Y. and Jha, A.K. (2013) Phylogenetic Diversity of Methanogenic Archaea and Kinetics of Methane Production at Slightly Acidic Conditions of an Anaerobic Sludge. International. Journal of Agriculture and Biology, 15, 347-351.

[81] Bräuer, S.L., Cadillo-Quiroz, H., Ward, R.J., Yavitt, J.B. and Zinder, S.H. (2011) Methanoregula Boonei gen. nov., sp. nov., an Acidiphilic Methanogen Isolated from an Acidic Peat Bog. International Journal of Systematic and Evolutionary Microbiology, 61, 45-52. https://doi.org/10.1099/ijs.0.021782-0

[82] Nam, Y.D., Sung, Y., Chang, H.W., Roh, S.W., Kim, K.H., Rhee, S.K., et al. (2008) Characterization of the Depth-Related Changes in the Microbial Communities in Lake Hovsgol Sediment by $16 \mathrm{~S}$ rRNA Gene-Based Approaches. The Journal of Microbiology, 46, 125-136. https://doi.org/10.1007/s12275-007-0189-1

[83] Lim, J., Woodward, J., Tulaczyk, S., Christoffersen, P. and Cummings, S.P. (2010) Analysis of the Microbial Community and Geochemistry of a Sediment Core from Great Slave Lake, Canada. Antonie van Leeuwenhoek, 99, 423-430. https://doi.org/10.1007/s10482-010-9500-y

[84] Lucheta, A.R., Otero, X.L., Macías, F. and Lambais, M.R. (2013) Bacterial and Archaeal Communities in the Acid Pit Lake Sediments of a Chalcopyrite Mine. Extremophiles. Life under Extreme Conditions, 17, 941-951.

[85] Zhang, J., Yang, Y., Zhao, L., Li, Y., Xie, S. and Liu, Y. (2014) Distribution of Sediment Bacterial and Archaeal Communities in Plateau Freshwater Lakes. Applied Microbiology and Biotechnology, 99, 3291-3302. https://doi.org/10.1007/s00253-014-6262-x

[86] Liao, X., Chen, C., Zhang, J., Dai, Y., Zhang, X. and Xie, S. (2014) Operational Performance, Biomass and Microbial Community Structure: Impacts of Backwashing on Drinking Water Biofilter. Environmental Science and Pollution Research, 22, 546-554. https://doi.org/10.1007/s11356-014-3393-7

[87] Bai, Y., Shi, Q., Wen, D., Li, Z., Jefferson, W.A., Feng, C., et al. (2012) Bacterial Communities in the Sediments of Dianchi Lake, a Partitioned Eutrophic Waterbody in China. PLoS ONE, 7, e37796. https://doi.org/10.1371/journal.pone.0037796

[88] Fierer, N. and Jackson, R.B. (2006) The Diversity and Biogeography of Soil Bacterial Communities. PNAS, 103, 626-631. https://doi.org/10.1073/pnas.0507535103

[89] Sandaa, R.A., Enger, O. and Torsvik, V. (1999) Abundance and Diversity of Archaea 
in Heavy-Metal-Contaminated Soils. Applied and Environmental Microbiology, 65, 3293-3297.

[90] Li, P., Jiang, D., Li, B., Dai, X., Wang, Y., Jiang, Z., et al. (2014) Comparative Survey of Bacterial and Archaeal Communities in High Arsenic Shallow Aquifers Using 454 Pyrosequencing and Traditional Methods. Ecotoxicology, 23, 1878-1889. https://doi.org/10.1007/s10646-014-1316-5 


\section{Supplementary Material}

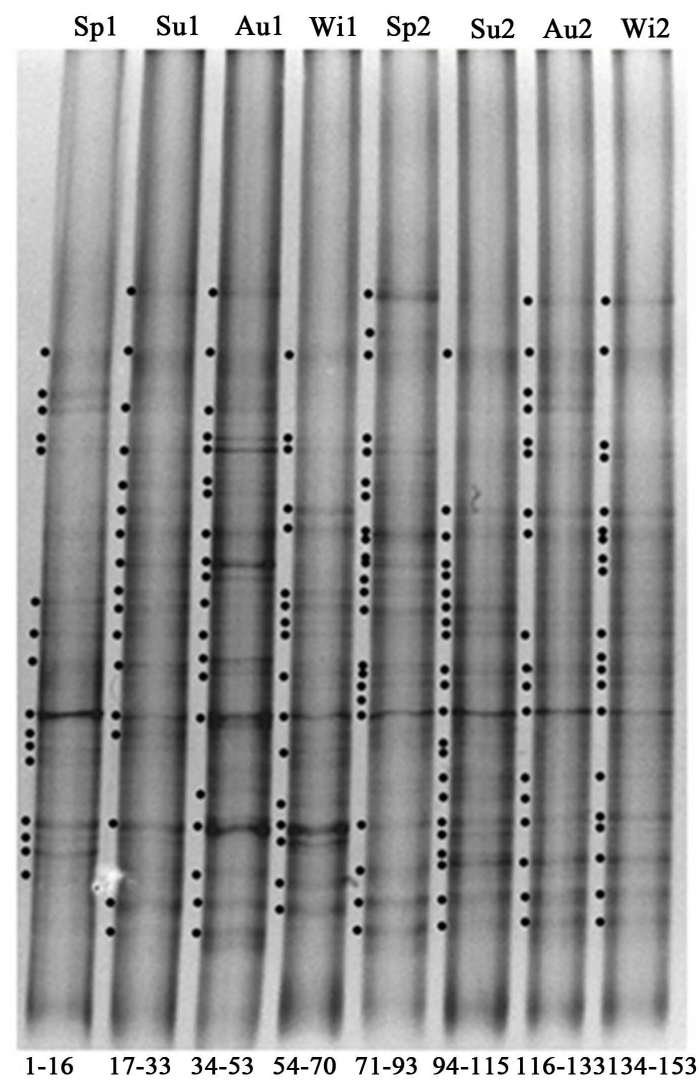

Figure S1. Bacterial species composition in the sediments of Lake Pamvotis as revealed by $16 \mathrm{~S}$ rDNADGGE profiles. All dotted bands were excised, reamplified and sequenced. Sp: Spring, Su: Summer, Au: Autumn, Wi: Winter, 1: SS1, 2: SS2.
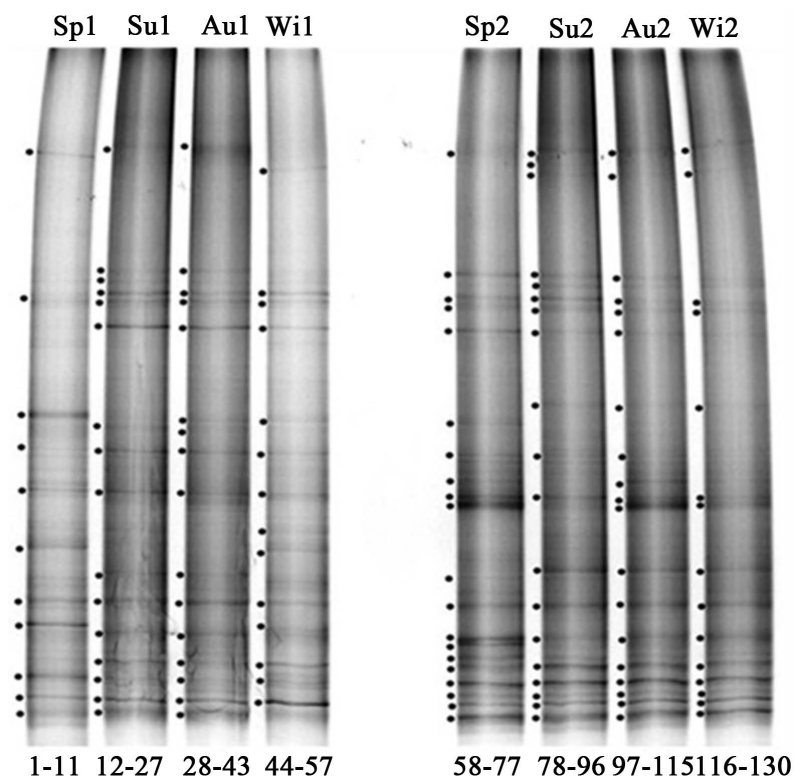

Figure S2. Archaeal species composition in the sediments of Lake Pamvotis as revealed by $16 \mathrm{~S}$ rDNADGGE profiles. All dotted bands were excised, reamplified and sequenced. Sp: Spring, Su: Summer, Au: Autumn, Wi: Winter, 1: SS1, 2: SS2. 


\section{Clone Affiliation of Bacteria}

Table S1. Clone affiliation of bacterial 16S rDNA sequences retrieved from Lake Pamvotis sediments, to known $16 \mathrm{~S}$ rDNA sequences in public databases

\begin{tabular}{|c|c|c|c|}
\hline $\begin{array}{l}\text { Clone } \\
\text { name }\end{array}$ & $\begin{array}{l}\text { Accession } \\
\text { number }\end{array}$ & $\begin{array}{l}\% \text { query, } \% \\
\text { identity } \\
\text { culture } \\
\text { collection }\end{array}$ & $\begin{array}{l}\% \text { query, } \% \text { identity } \\
\text { cultured species }\end{array}$ \\
\hline BacPamv1 & KР244158 & $\begin{array}{c}100 \% 99 \% \\
\text { HM153665.1 }\end{array}$ & $\begin{array}{c}100 \% 99 \% \\
\text { NR029024.1 } \\
\text { Hydrogenophaga defluvii BSB } 9.5\end{array}$ \\
\hline BacPamv2 & KР244159 & $\begin{array}{c}99 \% 98 \% \\
\text { FQ659268.1 }\end{array}$ & $\begin{array}{c}99 \% 88 \% \\
\text { NR074757.1 } \\
\text { Treponema caldaria DSM } 7334\end{array}$ \\
\hline BacPamv3 & KP244160 & $\begin{array}{c}100 \% 93 \% \\
\text { GQ472421.1 }\end{array}$ & $\begin{array}{c}100 \% 83 \% \\
\text { NR075001.1 } \\
\text { Moorella thermoacetica ATCC } 39073\end{array}$ \\
\hline BacPamv4 & KP244161 & $\begin{array}{c}100 \% 99 \% \\
\text { HM243914.1 }\end{array}$ & $\begin{array}{c}100 \% 86 \% \\
\text { NR074330.1 } \\
\text { Nitrosococcus oceani ATCC } 19707\end{array}$ \\
\hline BacPamv5 & KP244162 & $\begin{array}{c}100 \% 96 \% \\
J N 805711.1\end{array}$ & $\begin{array}{c}100 \% 92 \% \\
\text { NR075002.1 } \\
\text { Syntrophobacter fumaroxidans MPOB }\end{array}$ \\
\hline BacPamv6 & KP244163 & $\begin{array}{c}100 \% 87 \% \\
J Q 516335.1\end{array}$ & $\begin{array}{c}100 \% 78 \% \\
\text { NR075009.1 } \\
\text { Geobacter sulfurreducens PCA }\end{array}$ \\
\hline BacPamv7 & KP244164 & $\begin{array}{c}100 \% 95 \% \\
\text { HQ910926.1 }\end{array}$ & $\begin{array}{c}100 \% 85 \% \\
\text { NR028695.1 } \\
\text { Lewinella nigricans SS-2 }\end{array}$ \\
\hline BacPamv8 & KР244165 & $\begin{array}{c}100 \% 99 \% \\
\text { KC } 432448.1\end{array}$ & $\begin{array}{c}100 \% 86 \% \\
\text { NR104911.1 } \\
\text { Vampirovibrio chlorellavorus ICPB } 3707\end{array}$ \\
\hline BacPamv9A & KP244166 & $\begin{array}{c}100 \% 99 \% \\
\text { KC } 432448.1\end{array}$ & $\begin{array}{c}100 \% 85 \% \\
\text { NR0 } 03559.1 \\
\text { Gracilibacter thermotolerans JW/YJL-S1 }\end{array}$ \\
\hline BacPamv9B & KP244167 & $\begin{array}{l}100 \% 100 \% \\
J F 265807.1\end{array}$ & $\begin{array}{c}100 \% 96 \% \\
\text { NR029287.1 } \\
\text { Nitrospira moscoviensis NSP M-1 }\end{array}$ \\
\hline BacPamv10 & KP244168 & $\begin{array}{c}100 \% 99 \% \\
\text { HM346679.1 }\end{array}$ & $\begin{array}{c}100 \% 94 \% \\
\text { NR042824.1 } \\
\text { Collimonas arenae NCCB } 100031\end{array}$ \\
\hline BacPamv11 & KР244169 & $\begin{array}{c}100 \% 92 \% \\
\text { EF203209.1 }\end{array}$ & $\begin{array}{c}100 \% 85 \% \\
\text { NR036977.1 } \\
\text { Thiococcus pfennigii } 4250\end{array}$ \\
\hline BacPamv12 & KP244170 & $\begin{array}{c}100 \% 99 \% \\
\mathrm{AB} 661525.1\end{array}$ & $\begin{array}{c}100 \% 84 \% \\
\text { NR109681.1 } \\
\text { Thermoanaerobaculum aquaticum MP-01 }\end{array}$ \\
\hline
\end{tabular}




\section{Continued}

\begin{tabular}{|c|c|c|c|}
\hline BacPamv13A & KP244171 & $\begin{array}{c}100 \% 99 \% \\
\mathrm{AB} 196055.1\end{array}$ & $\begin{array}{c}100 \% 92 \% \\
\text { NR044309.1 } \\
\text { Steroidobacter denitrificans } \text { F5 }\end{array}$ \\
\hline BacPamv13B & KP244172 & $\begin{array}{c}99 \% 93 \% \\
\text { HF677528.1 }\end{array}$ & $\begin{array}{c}98 \% 85 \% \\
\text { NR075001.1 } \\
\text { Moorella thermoacetica ATCC } 39073\end{array}$ \\
\hline BacPamv13C & KP244173 & $\begin{array}{c}100 \% 99 \% \\
\text { КС } 989704.1\end{array}$ & $\begin{array}{c}100 \% 99 \% \\
\text { NR074314.1 } \\
\text { Microcystis aeroginosa NIES-843 }\end{array}$ \\
\hline BacPamv14 & KP244174 & $\begin{array}{c}100 \% 90 \% \\
\text { JN473052.1 }\end{array}$ & $\begin{array}{c}100 \% 78 \% \\
\text { NR075001.1 } \\
\text { Moorella thermoacetica ATCC } 39073\end{array}$ \\
\hline BacPamv15 & KP244175 & $\begin{array}{c}100 \% 99 \% \\
\text { HM346679.1 }\end{array}$ & $\begin{array}{c}100 \% 93 \% \\
\text { NR042824.1 } \\
\text { Collimonas arenae NCCB } 100031\end{array}$ \\
\hline BacPamv16 & KP244176 & $\begin{array}{l}100 \% 99 \% \\
J N 868188.1\end{array}$ & $\begin{array}{c}100 \% 92 \% \\
\text { NR043249.1 } \\
\text { Denitratisoma oestradiolicum AcBE2-1 }\end{array}$ \\
\hline BacPamv17A & KP244177 & $\begin{array}{c}\text { 98\% 96\% } \\
\text { JQ583178.1 }\end{array}$ & $\begin{array}{c}97 \% 94 \% \\
\text { NR074351.1 } \\
\text { Candidatus solibcter Ellin } 6076\end{array}$ \\
\hline BacPamv17B & KP244178 & $\begin{array}{c}100 \% 96 \% \\
\text { HQ904418.1 }\end{array}$ & $\begin{array}{c}100 \% 85 \% \\
\text { NR102459.1 } \\
\text { Chamaesiphon minutes PCC } 6605\end{array}$ \\
\hline BacPamv18 & KP244179 & $\begin{array}{c}100 \% 99 \% \\
\text { KF287757.1 }\end{array}$ & $\begin{array}{c}100 \% 99 \% \\
\text { NR025816.1 } \\
\text { Porphyrobacter donghaensis SW-132 }\end{array}$ \\
\hline BacPamv19 & KР244180 & $\begin{array}{c}100 \% 99 \% \\
\text { KC248046.1 }\end{array}$ & $\begin{array}{c}100 \% 98 \% \\
\text { NR042941.1 } \\
\text { Paucibacter toxinivorans } 2 \mathrm{C} 20\end{array}$ \\
\hline BacPamv20A & KP244181 & $\begin{array}{c}100 \% 97 \% \\
\text { HQ661184.1 }\end{array}$ & $\begin{array}{c}100 \% 84 \% \\
\text { NR102468.1 } \\
\text { Stanieria cyanospaera PCC } 7437\end{array}$ \\
\hline BacPamv20B & KP244182 & $\begin{array}{c}100 \% 89 \% \\
\text { EU376186.1 }\end{array}$ & $\begin{array}{c}100 \% 79 \% \\
\text { NR102456.1 } \\
\text { Leptolyngbya PCC } 7376\end{array}$ \\
\hline BacPamv21 & KP244183 & $\begin{array}{c}100 \% 99 \% \\
\text { EU104276.1 }\end{array}$ & $\begin{array}{c}100 \% 89 \% \\
\text { NR040990.1 } \\
\text { Owenweeksia hongkongensis UST } 20020801\end{array}$ \\
\hline BacPamv22 & KP244184 & $\begin{array}{c}100 \% 96 \% \\
\text { HQ661184.1 }\end{array}$ & $\begin{array}{c}100 \% 84 \% \\
\text { NR102456.1 } \\
\text { Leptolyngbya PCC } 7376\end{array}$ \\
\hline BacPamv23 & KP244185 & $\begin{array}{c}100 \% 96 \% \\
\text { KF939466.1 }\end{array}$ & $\begin{array}{c}100 \% 94 \% \\
\text { NR102987.1 } \\
\text { Clostridium clariflavum DSM } 19732\end{array}$ \\
\hline
\end{tabular}




\section{Continued}

\begin{tabular}{|c|c|c|c|}
\hline BacPamv24A & KP244186 & $\begin{array}{c}100 \% 99 \% \\
\text { KC541335.1 }\end{array}$ & $\begin{array}{c}100 \% 93 \% \\
\text { NR0 } 44309.1 \\
\text { Steroidobacter denitrificans FS }\end{array}$ \\
\hline BacPamv24B & KP244187 & $\begin{array}{c}99 \% 97 \% \\
\text { AY693835.1 }\end{array}$ & $\begin{array}{c}99 \% 83 \% \\
\text { NR025079.1 } \\
\text { Desulfomonile limimaris DSB-M }\end{array}$ \\
\hline BacPamv25 & KP244188 & $\begin{array}{c}100 \% 99 \% \\
\text { HM243891.1 }\end{array}$ & $\begin{array}{c}100 \% 88 \% \\
\text { NR074345.1 } \\
\text { Thermodesulfovibrio yellowstonii DSM } 11347\end{array}$ \\
\hline BacPamv26 & KP244189 & $\begin{array}{c}100 \% 99 \% \\
\text { KC666549.1 }\end{array}$ & $\begin{array}{c}100 \% 97 \% \\
\text { NR043993.1 } \\
\text { Rheinheimera tangshanensis JA3-B52 }\end{array}$ \\
\hline BacPamv27 & KР244190 & $\begin{array}{c}100 \% 93 \% \\
\text { HQ246251.1 }\end{array}$ & $\begin{array}{c}100 \% 93 \% \\
\text { NR029024.1 } \\
\text { Hydrogenophaga defluvii BSB } 9.5\end{array}$ \\
\hline BacPamv28 & KP244191 & $\begin{array}{c}100 \% 91 \% \\
\mathrm{AB} 722172.1\end{array}$ & $\begin{array}{c}100 \% 84 \% \\
\text { NR037137.1 } \\
\text { Treponema medium G7201 }\end{array}$ \\
\hline BacPamv29 & KP244192 & $\begin{array}{c}99 \% 91 \% \\
\mathrm{AB} 661540.1\end{array}$ & $\begin{array}{c}99 \% 86 \% \\
\text { NR074757.1 } \\
\text { Treponema caldaria DSM } 7334\end{array}$ \\
\hline BacPamv30 & KP244193 & $\begin{array}{c}100 \% 99 \% \\
\text { JN257048.1 }\end{array}$ & $\begin{array}{c}100 \% 95 \% \\
\text { NR074317.1 } \\
\text { Nostoc punctiforme PCC } 73102\end{array}$ \\
\hline BacPamv31 & KP244194 & $\begin{array}{c}100 \% 91 \% \\
\text { GQ356966.1 }\end{array}$ & $\begin{array}{c}100 \% 84 \% \\
\text { NR025150.1 } \\
\text { Desulfobulbus mediterraneus } 86 \mathrm{FS} 1\end{array}$ \\
\hline BacPamv32 & KP244195 & $\begin{array}{c}100 \% 99 \% \\
\text { KF556697.1 }\end{array}$ & $\begin{array}{c}100 \% 98 \% \\
\text { NR074760.1 } \\
\text { Albidiferax ferrireducens } \mathrm{T} 118\end{array}$ \\
\hline BacPamv33 & KP244196 & $\begin{array}{c}100 \% 99 \% \\
\text { AB793710.1 }\end{array}$ & $\begin{array}{c}100 \% 97 \% \\
\text { NR026102.1 } \\
\text { Clostridium papyrosolvens DSM } 2792\end{array}$ \\
\hline BacPamv34 & KP244197 & $\begin{array}{c}100 \% 92 \% \\
\text { GU208417.1 }\end{array}$ & $\begin{array}{c}100 \% 85 \% \\
\text { NR028745.1 } \\
\text { Thioalkalivibrio denitrificans ALJD }\end{array}$ \\
\hline BacPamv35 & KP244198 & $\begin{array}{c}100 \% 89 \% \\
\text { AM181924.1 }\end{array}$ & $\begin{array}{c}100 \% 84 \% \\
\text { NR043929.1 } \\
\text { Skermanella aerolata } 5416 \mathrm{~T}-32\end{array}$ \\
\hline BacPamv36 & KP244199 & $\begin{array}{c}100 \% 99 \% \\
\text { HG792168.1 }\end{array}$ & $\begin{array}{c}100 \% 99 \% \\
\text { NR036911.2 } \\
\text { Aeromonas media RM }\end{array}$ \\
\hline BacPamv37 & KP244200 & $\begin{array}{c}100 \% 99 \% \\
\text { KC815481.1 }\end{array}$ & $\begin{array}{c}100 \% 99 \% \\
\text { NR102447.1 } \\
\text { Cyanobium gracile PCC } 6307\end{array}$ \\
\hline
\end{tabular}




\section{Continued}

\begin{tabular}{|c|c|c|c|}
\hline BacPamv38 & KР244201 & $\begin{array}{c}100 \% 99 \% \\
\text { LK054500.1 }\end{array}$ & $\begin{array}{c}100 \% 99 \% \\
\text { NR075062.2 } \\
\text { Micrococcus luteus NCTC } 2665\end{array}$ \\
\hline BacPamv39 & KP244202 & $\begin{array}{c}100 \% 92 \% \\
\text { KF384384.1 }\end{array}$ & $\begin{array}{c}100 \% 87 \% \\
\text { NR104682.1 } \\
\text { Marinilabilia salmonicolor JCM 21150 NBRC } 15946\end{array}$ \\
\hline BacPamv40 & KP244203 & $\begin{array}{c}100 \% 98 \% \\
\text { EU376186.1 }\end{array}$ & $\begin{array}{c}100 \% 83 \% \\
\text { NR102456.1 } \\
\text { Leptolyngbya PCC } 7376\end{array}$ \\
\hline BacPamv41 & KР244204 & $\begin{array}{c}100 \% 93 \% \\
\text { DQ642331.1 }\end{array}$ & $\begin{array}{c}100 \% 90 \% \\
\text { NR041306.1 } \\
\text { Syntrophorhabdus aromaticivorans } \mathrm{U} 1\end{array}$ \\
\hline BacPamv42 & KP244205 & $\begin{array}{c}100 \% 96 \% \\
\text { GU197631.1 }\end{array}$ & $\begin{array}{c}100 \% 92 \% \\
\text { NR074317.1 } \\
\text { Nostoc punctiforme PCC } 73102\end{array}$ \\
\hline BacPamv43 & KP244206 & $\begin{array}{c}100 \% 88 \% \\
\mathrm{AB} 186797.1\end{array}$ & $\begin{array}{c}100 \% 81 \% \\
\text { NR043385.1 } \\
\text { Dictyoglomus turgidum DSM } 6724\end{array}$ \\
\hline BacPamv44 & KP244207 & $\begin{array}{c}100 \% 95 \% \\
\mathrm{AB} 486150.1\end{array}$ & $\begin{array}{c}100 \% 89 \% \\
\text { NR075011.1 } \\
\text { Geobacter metallireducens GS-15 }\end{array}$ \\
\hline BacPamv45 & KP244208 & $\begin{array}{c}100 \% 99 \% \\
\text { KC432448.1 }\end{array}$ & $\begin{array}{c}100 \% 85 \% \\
\text { NR0 } 43559.1 \\
\text { Gracilibacter thermotolerans JW/YJL-S1 }\end{array}$ \\
\hline BacPamv46 & KP244209 & $\begin{array}{c}100 \% 96 \% \\
\text { GU454906.1 }\end{array}$ & $\begin{array}{c}100 \% 87 \% \\
\text { NR074757.1 } \\
\text { Treponema caldaria DSM } 7334\end{array}$ \\
\hline BacPamv47 & KP244210 & $\begin{array}{c}100 \% 99 \% \\
\text { KC432448.1 }\end{array}$ & $\begin{array}{c}100 \% 84 \% \\
\text { NR043559.1 } \\
\text { Gracilibacter thermotolerans JW/YJL-S1 }\end{array}$ \\
\hline BacPamv48 & KP244211 & $\begin{array}{c}99 \% 92 \% \\
\mathrm{AB} 240355.1\end{array}$ & $\begin{array}{c}99 \% 84 \% \\
\text { NR044075.1 } \\
\text { Thermodesulfovibrio hydrogeniphiles HbrS }\end{array}$ \\
\hline BacPamv49 & KP244212 & $\begin{array}{c}100 \% 93 \% \\
\text { JN397726.1 }\end{array}$ & $\begin{array}{c}100 \% 91 \% \\
\text { NR028715.1 } \\
\text { Acidovorax temperans PHL }\end{array}$ \\
\hline BacPamv50 & KР244213 & $\begin{array}{c}100 \% 99 \% \\
\text { JX223096.1 }\end{array}$ & $\begin{array}{c}100 \% 99 \% \\
\text { NR040800.1 } \\
\text { Vogesella indigofera ATCC } 19706\end{array}$ \\
\hline BacPamv51 & KP244214 & $\begin{array}{c}100 \% 96 \% \\
\text { JQ624950.1 }\end{array}$ & $\begin{array}{c}100 \% 92 \% \\
\text { NR026102.1 } \\
\text { Clostridium papyrosolvens DSM } 2792\end{array}$ \\
\hline
\end{tabular}




\section{Clone affiliation of culturable Bacteria}

Table S2. Sequence analysis of $16 \mathrm{~S}$ rDNA sequences retrieved from cultured bacterial isolates from Lake Pamvotis sediments.

\begin{tabular}{|c|c|c|c|}
\hline Clone name & $\begin{array}{c}\text { Accession } \\
\text { number }\end{array}$ & $\begin{array}{l}\% \text { query, } \% \\
\text { identity } \\
\text { culture } \\
\text { collection }\end{array}$ & $\%$ query, $\%$ identity cultured species \\
\hline PamvBac iso.1 & KU862661 & $\begin{array}{l}100 \% 100 \% \\
\text { KF481602.1 }\end{array}$ & $\begin{array}{c}100 \% 99 \% \\
\text { NR042502.1 } \\
\text { Massilia aurea AP13 }\end{array}$ \\
\hline PamvBac iso. 2 & KU862662 & $\begin{array}{c}100 \% 99 \% \\
\text { KF556686.1 }\end{array}$ & $\begin{array}{c}100 \% 97 \% \\
\text { NR043699.1 } \\
\text { Rheinheimera chironomi K19414 }\end{array}$ \\
\hline PamvBac iso. 3 & KU862663 & $\begin{array}{c}100 \% 99 \% \\
\text { EF471218.1 }\end{array}$ & $\begin{array}{c}100 \% 99 \% \\
\text { NR042596.1 } \\
\text { Cryseobacterium luteum } \mathrm{P} 456 / 04\end{array}$ \\
\hline PamvBac iso. 4 & KU862664 & $\begin{array}{c}100 \% 99 \% \\
\text { JX223096.1 }\end{array}$ & $\begin{array}{c}100 \% 99 \% \\
\text { NR040800.1 } \\
\text { Vogesella indigofera ATCC } 19706\end{array}$ \\
\hline PamvBac iso. 5 & KU862665 & $\begin{array}{c}100 \% 99 \% \\
\text { KF556697.1 }\end{array}$ & $\begin{array}{c}100 \% 98 \% \\
\text { NR114646.1 } \\
\text { Rhodoferax ferrireducens } \text { T118 }\end{array}$ \\
\hline PamvBac iso.6 & KU862666 & $\begin{array}{c}100 \% 99 \% \\
\text { HG792168.1 }\end{array}$ & $\begin{array}{c}100 \% 99 \% \\
\text { NR036911.2 } \\
\text { Aeromonas media RM }\end{array}$ \\
\hline PamvBac iso.7 & KU862667 & $\begin{array}{c}100 \% 99 \% \\
\text { KF555636.1 }\end{array}$ & $\begin{array}{c}100 \% 99 \% \\
\text { NR041057.1 } \\
\text { Flavobacterium frigidimaris KUC-1 }\end{array}$ \\
\hline PamvBac iso. 8 & KU862668 & $\begin{array}{l}100 \% 99 \% \\
\text { JF145482.1 }\end{array}$ & $\begin{array}{c}100 \% 99 \% \\
\text { NR044292.1 } \\
\text { Flavobacterium resistens BD-b365 }\end{array}$ \\
\hline PamvBac iso.9 & KU862669 & $\begin{array}{c}100 \% 99 \% \\
\text { KC666807.1 }\end{array}$ & $\begin{array}{c}100 \% 99 \% \\
\text { NR025425.1 } \\
\text { Acinetobacteria parvus LUH } 4616\end{array}$ \\
\hline PamvBac iso. 10 & KU862670 & $\begin{array}{l}100 \% 100 \% \\
\text { JX657101.1 }\end{array}$ & $\begin{array}{c}100 \% 98 \% \\
\text { NR108576.1 } \\
\text { Flavobacterium compostarboris } 15 \mathrm{C} 3\end{array}$ \\
\hline PamvBac iso. 11 & KU862671 & $\begin{array}{c}100 \% 99 \% \\
\text { KC666549.1 }\end{array}$ & $\begin{array}{c}100 \% 97 \% \\
\text { NR043993.1 } \\
\text { Rheinheimera tangshanensis JA3-B52 }\end{array}$ \\
\hline PamvBac iso.12 & KU862672 & $\begin{array}{c}100 \% 99 \% \\
\text { KC294042.1 }\end{array}$ & $\begin{array}{c}100 \% 99 \% \\
\text { NR029319.1 } \\
\text { Pseudomonas anguilliseptica S1 }\end{array}$ \\
\hline PamvBac iso. 13 & KU862673 & $\begin{array}{c}100 \% 99 \% \\
\text { GU291856.1 }\end{array}$ & $\begin{array}{c}100 \% 98 \% \\
\text { NR109728.1 } \\
\text { Flavobacterium cutihirudinis } \mathrm{E} 89\end{array}$ \\
\hline PamvBac iso. 14 & KU862674 & $\begin{array}{c}\text { 97\% 99\% } \\
\text { JQ317797.1 }\end{array}$ & $\begin{array}{c}97 \% 98 \% \\
\text { NR029319.1 } \\
\text { Pseudomonas anguilliseptica S1 }\end{array}$ \\
\hline
\end{tabular}




\section{Continued}

\begin{tabular}{|c|c|c|c|}
\hline PamvBac iso. 15 & KU862675 & $\begin{array}{c}100 \% 99 \% \\
\text { HM149209.1 }\end{array}$ & $\begin{array}{c}100 \% 99 \% \\
\text { NR044581.1 } \\
\text { Flavobacterium chungangense CJ7 }\end{array}$ \\
\hline PamvBac iso.16 & KU862676 & $\begin{array}{c}99 \% 99 \% \\
\text { KF894688.1 }\end{array}$ & $\begin{array}{c}99 \% 98 \% \\
\text { NR115957.1 } \\
\text { Chryseobacterium flavum strain CW-E2 }\end{array}$ \\
\hline PamvBac iso.17 & KU862677 & $\begin{array}{c}100 \% 99 \% \\
\text { KC248046.1 }\end{array}$ & $\begin{array}{c}100 \% 98 \% \\
\text { NR042941.1 } \\
\text { Paucibacter toxinivorans } 2 \mathrm{C} 20\end{array}$ \\
\hline PamvBac iso. 18 & KU862678 & $\begin{array}{c}100 \% 93 \% \\
\text { HQ246251.1 }\end{array}$ & $\begin{array}{c}100 \% 93 \% \\
\text { NR029024.1 } \\
\text { Hydrogenophaga defluvii BSB } 9.5\end{array}$ \\
\hline PamvBac iso.19 & KU862679 & $\begin{array}{l}100 \% 100 \% \\
\text { KC294042.1 }\end{array}$ & $\begin{array}{c}100 \% 100 \% \\
\text { NR029319.1 } \\
\text { Pseudomonas anguilliseptica S1 }\end{array}$ \\
\hline PamvBac iso. 20 & KU862680 & $\begin{array}{c}100 \% 99 \% \\
\text { HM153665.1 }\end{array}$ & $\begin{array}{c}100 \% 99 \% \\
\text { NR029024.1 } \\
\text { Hydrogenophaga defluvii BSB } 9.5\end{array}$ \\
\hline PamvBac iso. 21 & KU862681 & $\begin{array}{c}100 \% 99 \% \\
\text { NR109522.1 }\end{array}$ & $\begin{array}{c}100 \% 99 \% \\
\text { NR109522.1 } \\
\text { Flavobacterium fontis MIC } 3010\end{array}$ \\
\hline PamvBac iso. 22 & KU862682 & $\begin{array}{c}100 \% 99 \% \\
\text { KF287757.1 }\end{array}$ & $\begin{array}{c}100 \% 99 \% \\
\text { NR025816.1 } \\
\text { Porphyrobacter donghaensis SW-132 }\end{array}$ \\
\hline PamvBac iso. 23 & KU862683 & $\begin{array}{c}100 \% 99 \% \\
\text { LK054500.1 }\end{array}$ & $\begin{array}{c}100 \% 99 \% \\
\text { NR075062.2 } \\
\text { Micrococcus luteus NCTC } 2665\end{array}$ \\
\hline
\end{tabular}

Table S3. Distribution of bacterial 16S rDNA clones in Lake Pamvotis sample stations.

\begin{tabular}{|c|c|c|c|c|c|c|c|c|c|c|c|}
\hline & \multirow{2}{*}{ clone name } & \multirow{2}{*}{ SS1 } & \multirow{2}{*}{ SS2 } & \multicolumn{2}{|c|}{ Sp. } & \multicolumn{2}{|c|}{ Su. } & \multicolumn{2}{|c|}{$\mathrm{Au}$. } & \multicolumn{2}{|c|}{ Wi. } \\
\hline & & & & SS1 & SS2 & SS1 & SS2 & SS1 & SS2 & SS1 & SS2 \\
\hline \multirow[t]{7}{*}{$\gamma$-Proteobacteria } & BacPamv26 & $\sqrt{ }$ & $\sqrt{ }$ & - & $\sqrt{ }$ & - & - & $\sqrt{ }$ & - & - & - \\
\hline & BacPamv36 & $\sqrt{ }$ & - & - & - & - & - & - & - & $\sqrt{ }$ & - \\
\hline & BacPamv13A & $\sqrt{ }$ & - & $\sqrt{ }$ & - & - & - & - & - & - & - \\
\hline & BacPamv24A & $\sqrt{ }$ & $\sqrt{ }$ & - & - & $\sqrt{ }$ & $\sqrt{ }$ & $\sqrt{ }$ & - & - & - \\
\hline & BacPamv4 & $\sqrt{ }$ & $\sqrt{ }$ & $\sqrt{ }$ & $\sqrt{ }$ & - & - & $\sqrt{ }$ & $\sqrt{ }$ & $\sqrt{ }$ & $\sqrt{ }$ \\
\hline & BacPamv35 & $\sqrt{ }$ & - & - & - & - & - & - & - & $\sqrt{ }$ & - \\
\hline & BacPamv11 & $\sqrt{ }$ & - & $\sqrt{ }$ & - & - & - & - & - & - & - \\
\hline TOTAL SEQUENCES & & 7 & 3 & 3 & 2 & 1 & 1 & 3 & 1 & 3 & 1 \\
\hline \multirow[t]{4}{*}{$\beta$-Proteobacteria } & BacPamv10 & $\sqrt{ }$ & - & $\sqrt{ }$ & - & $\sqrt{ }$ & - & - & - & - & - \\
\hline & BacPamv15 & $\sqrt{ }$ & $\sqrt{ }$ & $\sqrt{ }$ & - & - & $\sqrt{ }$ & - & $\sqrt{ }$ & - & $\sqrt{ }$ \\
\hline & BacPamv50 & - & $\sqrt{ }$ & - & - & - & $\sqrt{ }$ & - & - & - & - \\
\hline & BacPamv16 & $\sqrt{ }$ & $\sqrt{ }$ & $\sqrt{ }$ & $\sqrt{ }$ & - & - & $\sqrt{ }$ & - & - & - \\
\hline
\end{tabular}




\section{Continued}

TOTAL SEQUENCES

a-Proteobacteria

TOTAL SEQUENCES

Bacteroidetes

TOTAL SEQUENCES

$\delta$-Proteobacteria

OTAL SEQUENCES

Actinobacteria

TOTAL SEQUENCES

Gemmatimonadetes TOTAL SEQUENCES

Spirochaetes

Spirochaetes
$\frac{\text { TOTAL SEQUENCES }}{\text { Planctomycetes }}$

\section{TOTAL SEQUENCES}

Cyanobacteria

$\begin{array}{lllllllllll}\text { BacPamv27 } & \sqrt{ } & \sqrt{ } & - & - & - & \sqrt{ } & \sqrt{ } & - & - & - \\ \text { BacPamv49 } & - & \sqrt{ } & - & - & - & \sqrt{ } & - & \sqrt{ } & - & - \\ \text { BacPamv19 } & \sqrt{ } & \sqrt{ } & - & - & \sqrt{ } & \sqrt{ } & - & \sqrt{ } & \sqrt{ } & \sqrt{ } \\ \text { BacPamv1 } & \sqrt{ } & \sqrt{ } & \sqrt{ } & \sqrt{ } & \sqrt{ } & \sqrt{ } & \sqrt{ } & \sqrt{ } & \sqrt{ } & \sqrt{ } \\ \text { BacPamv32 } & \sqrt{ } & - & - & - & - & - & - & - & \sqrt{ } & - \\ & 7 & 7 & 4 & 2 & 3 & 6 & 3 & 4 & 3 & 3 \\ \text { BacPamv18 } & \sqrt{ } & - & - & - & \sqrt{ } & - & - & - & - & -\end{array}$

$\begin{array}{lllllllllll}1 & 0 & 0 & 0 & 1 & 0 & 0 & 0 & 0 & 0\end{array}$

BacPamv7

BacPamv21

BacPamv39

(2)

$$
22
$$

BacPamv24B

BacPamv44

BacPamv41

$\sqrt{ } \sqrt{ }$

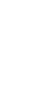

1
-

$$
\begin{aligned}
& 1 \\
& \sqrt{ } \\
& \sqrt{ }
\end{aligned}
$$$$
\begin{array}{llllll}
2 & 1 & 2 & 1 & 1 & 2
\end{array}
$$

BacPamv38

$$
1
$$$$
0
$$$$
3
$$$$
\begin{array}{ccccccccccc} 
& 0 & 1 & 0 & 1 & 0 & 0 & 0 & 0 & 0 & 0 \\
\operatorname{BacPamv34} & \sqrt{ } & \sqrt{ } & - & - & - & \sqrt{ } & - & - & \sqrt{ } & - \\
& 1 & 1 & 0 & 0 & 0 & 1 & 0 & 0 & 1 & 0
\end{array}
$$

BacPamv2

BacPamv29

BacPamv28

3

BacPamv14

BacPamv6

32

2

BacPamv20A

BacPamv40

BacPamv22

BacPamv20B

BacPamv17B

BacPamv30

BacPamv42

BacPamv37

BacPamv13C 


\section{Continued}

\begin{tabular}{|c|c|c|c|c|c|c|c|c|c|c|c|}
\hline TOTAL SEQUENCES & & 5 & 7 & 0 & 7 & 2 & 4 & 3 & 3 & 4 & 4 \\
\hline \multirow[t]{3}{*}{ Firmicutes } & BacPamv33 & $\sqrt{ }$ & $\sqrt{ }$ & - & - & - & $\sqrt{ }$ & - & - & $\sqrt{ }$ & - \\
\hline & BacPamv51 & - & $\sqrt{ }$ & - & - & - & - & - & - & - & $\sqrt{ }$ \\
\hline & BacPamv23 & $\sqrt{ }$ & - & - & - & $\sqrt{ }$ & - & - & - & - & - \\
\hline TOTAL SEQUENCES & & 2 & 2 & 0 & 0 & 1 & 1 & 0 & 0 & 1 & 1 \\
\hline \multirow[t]{5}{*}{ Nitrospirae } & BacPamv25 & $\sqrt{ }$ & $\sqrt{ }$ & - & $\sqrt{ }$ & $\sqrt{ }$ & $\sqrt{ }$ & $\sqrt{ }$ & $\sqrt{ }$ & - & $\sqrt{ }$ \\
\hline & BacPamv31 & $\sqrt{ }$ & - & - & - & - & - & $\sqrt{ }$ & - & - & - \\
\hline & BacPamv48 & - & $\sqrt{ }$ & - & - & - & $\sqrt{ }$ & - & $\sqrt{ }$ & - & $\sqrt{ }$ \\
\hline & BacPamv12 & $\sqrt{ }$ & - & $\sqrt{ }$ & - & - & - & - & - & - & - \\
\hline & BacPamv9B & $\sqrt{ }$ & - & $\sqrt{ }$ & - & $\sqrt{ }$ & - & - & - & - & - \\
\hline$\underline{\text { TOTAL SEQUENCES }}$ & & 4 & 2 & 2 & 1 & 2 & 2 & 2 & 2 & 0 & 2 \\
\hline \multirow[t]{4}{*}{ Acidobacteria } & BacPamv5 & $\sqrt{ }$ & $\sqrt{ }$ & $\sqrt{ }$ & $\sqrt{ }$ & $\sqrt{ }$ & - & $\sqrt{ }$ & $\sqrt{ }$ & $\sqrt{ }$ & $\sqrt{ }$ \\
\hline & BacPamv3 & $\sqrt{ }$ & $\sqrt{ }$ & $\sqrt{ }$ & - & $\sqrt{ }$ & - & $\sqrt{ }$ & $\sqrt{ }$ & - & - \\
\hline & BacPamv13B & $\sqrt{ }$ & - & - & - & $\sqrt{ }$ & - & $\sqrt{ }$ & - & $\sqrt{ }$ & - \\
\hline & BacPamv17A & $\sqrt{ }$ & $\sqrt{ }$ & - & $\sqrt{ }$ & $\sqrt{ }$ & - & - & $\sqrt{ }$ & - & - \\
\hline$\underline{\text { TOTAL SEQUENCES }}$ & & 4 & 3 & 2 & 2 & 4 & 0 & 3 & 3 & 2 & 1 \\
\hline Unclassified cluster I & BacPamv43 & - & $\sqrt{ }$ & - & $\sqrt{ }$ & - & $\sqrt{ }$ & - & $\sqrt{ }$ & - & $\sqrt{ }$ \\
\hline TOTAL SEQUENCES & & 0 & 1 & 0 & 1 & 0 & 1 & 0 & 1 & 0 & 1 \\
\hline \multirow[t]{4}{*}{ Unclassified cluster II } & BacPamv45 & - & $\sqrt{ }$ & - & $\sqrt{ }$ & - & - & - & - & - & - \\
\hline & BacPamv47 & - & $\sqrt{ }$ & - & - & - & $\sqrt{ }$ & - & - & - & - \\
\hline & BacPamv9A & $\sqrt{ }$ & $\sqrt{ }$ & $\sqrt{ }$ & $\sqrt{ }$ & - & $\sqrt{ }$ & $\sqrt{ }$ & $\sqrt{ }$ & $\sqrt{ }$ & $\sqrt{ }$ \\
\hline & BacPamv8 & $\sqrt{ }$ & - & $\sqrt{ }$ & - & $\sqrt{ }$ & - & - & - & - & - \\
\hline TOTAL SEQUENCES & & 2 & 3 & 2 & 2 & 1 & 2 & 1 & 1 & 1 & 1 \\
\hline Unclassified cluster III & BacPamv46 & - & $\sqrt{ }$ & - & - & - & $\sqrt{ }$ & - & - & - & - \\
\hline \multirow[t]{2}{*}{$\underline{\text { TOTAL SEQUENCES }}$} & & 0 & 1 & 0 & 0 & 0 & 1 & 0 & 0 & 0 & 0 \\
\hline & SS1 & SS2 & & & & & & & & & \\
\hline TOTAL SEQUENCES & 41 & 40 & & & & & & & & & \\
\hline \multicolumn{12}{|l|}{ SS1: Sample Station 1} \\
\hline \multicolumn{12}{|l|}{ SS2: Sample Station 2} \\
\hline \multicolumn{12}{|l|}{ Sp.: Spring } \\
\hline \multicolumn{12}{|l|}{ Su.: Summer } \\
\hline \multicolumn{12}{|l|}{ Au.: Autumn } \\
\hline Wi.: Winter & & & & & & & & & & & \\
\hline
\end{tabular}




\section{Clone Affiliation of Archaea}

Table S4. Clone affiliation of archaeal 16S rDNA sequences retrieved from Lake Pamvotis sediments, to known $16 \mathrm{~S}$ rDNA sequences from public databases.

\begin{tabular}{|c|c|c|c|}
\hline Clone name & $\begin{array}{c}\text { Accession } \\
\text { number }\end{array}$ & $\begin{array}{l}\% \text { query, \% } \\
\text { identity } \\
\text { culture } \\
\text { collection }\end{array}$ & $\%$ query, $\%$ identity cultured species \\
\hline ArcPamv1 & KC510289 & $\begin{array}{l}100 \% 96 \% \\
\text { JN617408 }\end{array}$ & $\begin{array}{c}100 \% 95 \% \\
\text { NR028163 } \\
\text { Methanolinea tarda NOBI-1 }\end{array}$ \\
\hline ArcPamv2 & KC510290 & $\begin{array}{l}100 \% 99 \% \\
\text { JN617359 }\end{array}$ & $\begin{array}{c}100 \% 95 \% \\
\text { NR } 044422 \\
\text { Methanosphaerula palustris strain E1-9c }\end{array}$ \\
\hline ArcPamv3A & KC510291 & $\begin{array}{l}100 \% 94 \% \\
\text { JX196214 }\end{array}$ & $\begin{array}{c}100 \% 79 \% \\
\text { NR028646 } \\
\text { Methanotorris formicicus strain Mc-S-70 }\end{array}$ \\
\hline ArcPamv3B & KC510292 & $\begin{array}{l}99 \% 89 \% \\
\text { JN853647 }\end{array}$ & $\begin{array}{c}100 \% 72 \% \\
\text { NR029140 } \\
\text { Methanococcus aeolicus Nankai-3 }\end{array}$ \\
\hline ArcPamv4A & KC510293 & $\begin{array}{c}100 \% 99 \% \\
\text { HM } 244131\end{array}$ & $\begin{array}{c}100 \% 95 \% \\
\text { NR044422 } \\
\text { Methanosphaerula palustris strain E1-9c }\end{array}$ \\
\hline ArcPamv4B & KC510294 & $\begin{array}{l}100 \% 99 \% \\
\text { JQ795001 }\end{array}$ & $\begin{array}{c}100 \% 80 \% \\
\text { NR042784 } \\
\text { Methanobrevibacter ruminantium strain M1 }\end{array}$ \\
\hline ArcPamv4C & KC510295 & $\begin{array}{l}100 \% 99 \% \\
\text { JX426833 }\end{array}$ & $\begin{array}{c}100 \% 96 \% \\
\text { NR044422 } \\
\text { Methanosphaerula palustris strain E1-9c }\end{array}$ \\
\hline ArcPamv5 & KC510296 & $\begin{array}{l}100 \% 99 \% \\
\text { JN } 617444\end{array}$ & $\begin{array}{c}100 \% 97 \% \\
\text { NR028242 } \\
\text { Methanosaeta concilii strain Opfikon }\end{array}$ \\
\hline ArcPamv6 & KC510297 & $\begin{array}{l}100 \% 98 \% \\
\text { DQ301909 }\end{array}$ & $\begin{array}{c}100 \% 95 \% \\
\text { NRO } 44422 \\
\text { Methanosphaerula palustris strain E1-9c }\end{array}$ \\
\hline ArcPamv7 & KC510298 & $\begin{array}{l}\text { 99\% 99\% } \\
\text { JQ794950 }\end{array}$ & $\begin{array}{c}99 \% 97 \% \\
\text { NR028163 } \\
\text { Methanolinea tarda NOBI-1 }\end{array}$ \\
\hline ArcPamv8A & KC510299 & $\begin{array}{c}100 \% 99 \% \\
\text { JF431625 }\end{array}$ & $\begin{array}{c}100 \% 78 \% \\
\text { NR029059 } \\
\text { Palaeococcus helgesonii strain PI1 }\end{array}$ \\
\hline ArcPamv8B & KC510300 & $\begin{array}{c}100 \% 99 \% \\
\text { FJ755715 }\end{array}$ & $\begin{array}{c}88 \% 95 \% \\
\text { NR028179 } \\
\text { Thermococcus thioreducens OGL-20P }\end{array}$ \\
\hline ArcPamv9 & KC510301 & $\begin{array}{l}100 \% 99 \% \\
\text { JQ245676 }\end{array}$ & $\begin{array}{c}100 \% 94 \% \\
\text { NR028163 } \\
\text { Methanolinea tarda NOBI-1 }\end{array}$ \\
\hline ArcPamv10 & KC510302 & $\begin{array}{l}100 \% 99 \% \\
\text { EF639431 }\end{array}$ & $\begin{array}{c}100 \% 96 \% \\
\text { NR028163 } \\
\text { Methanolinea tarda NOBI-1 }\end{array}$ \\
\hline
\end{tabular}




\section{Continued}

\begin{tabular}{|c|c|c|c|}
\hline ArcPamv11 & KC510303 & $\begin{array}{c}100 \% 99 \\
\text { JX426833 }\end{array}$ & $\begin{array}{c}100 \% 96 \% \\
\text { NR044422 } \\
\text { Methanosphaerula palustris strain E1-9c }\end{array}$ \\
\hline ArcPamv12 & KC510304 & $\begin{array}{l}99 \% 99 \% \\
\text { AY } 125724\end{array}$ & $\begin{array}{c}\text { 99\% 96\% NR028163 } \\
\text { Methanolinea tarda NOBI-1 }\end{array}$ \\
\hline ArcPamv13 & KC510305 & $\begin{array}{c}99 \% 99 \% \\
\text { DQ785302 }\end{array}$ & $\begin{array}{c}99 \% 95 \% \\
\text { NR044422 } \\
\text { Methanosphaerula palustris strain E1-9c }\end{array}$ \\
\hline ArcPamv14 & KC510306 & $\begin{array}{c}100 \% 99 \% \\
\text { HQ330724 }\end{array}$ & $\begin{array}{c}100 \% 95 \% \\
\text { NR044422 } \\
\text { Methanosphaerula palustris strain E1-9c }\end{array}$ \\
\hline ArcPamv15 & KC510307 & $\begin{array}{c}100 \% 98 \% \\
\text { HQ330702 }\end{array}$ & $\begin{array}{c}100 \% 91 \% \\
\text { NR044422 } \\
\text { Methanosphaerula palustris strain E1-9c }\end{array}$ \\
\hline ArcPamv16 & KC510308 & $\begin{array}{l}100 \% 99 \% \\
\text { JQ794997 }\end{array}$ & $\begin{array}{c}100 \% 96 \% \\
\text { NR044422 } \\
\text { Methanosphaerula palustris strain E1-9c }\end{array}$ \\
\hline ArcPamv17 & KC510309 & $\begin{array}{c}100 \% 99 \% \\
\text { AM503280 }\end{array}$ & $\begin{array}{c}100 \% 95 \% \\
\text { NR0 } 44422 \\
\text { Methanosphaerula palustris strain E1-9c }\end{array}$ \\
\hline ArcPamv18A & KC510310 & $\begin{array}{l}100 \% 98 \% \\
\text { EF639431 }\end{array}$ & $\begin{array}{c}100 \% 96 \% \\
\text { NR028163 } \\
\text { Methanolinea tarda NOBI-1 }\end{array}$ \\
\hline ArcPamv18B & KC510311 & $\begin{array}{l}100 \% 99 \% \\
\text { JX426828 }\end{array}$ & $\begin{array}{c}100 \% 80 \% \\
\text { NR042784 } \\
\text { Methanobrevibacter ruminantium M1 strain M1 }\end{array}$ \\
\hline ArcPamv20 & KC510312 & $\begin{array}{l}100 \% 99 \% \\
\text { FM165672 }\end{array}$ & $\begin{array}{c}100 \% 96 \% \\
\text { NR044422 } \\
\text { Methanosphaerula palustris strain E1-9c }\end{array}$ \\
\hline ArcPamv21A & KC510313 & $\begin{array}{l}100 \% 99 \% \\
\text { JQ795001 }\end{array}$ & $\begin{array}{c}100 \% 80 \% \\
\text { NR042784 } \\
\text { Methanobrevibacter ruminantium M1 strain M1 }\end{array}$ \\
\hline ArcPamv21B & KC510314 & $\begin{array}{l}\text { 100\% 99\% } \\
\text { JQ794995 }\end{array}$ & $\begin{array}{c}100 \% 80 \% \\
\text { NR042784 } \\
\text { Methanobrevibacter ruminantium M1 strain M1 }\end{array}$ \\
\hline ArcPamv21C & KC510315 & $\begin{array}{c}100 \% 99 \% \\
\text { JF431702 }\end{array}$ & $\begin{array}{c}100 \% 78 \% \\
\text { NR029055 } \\
\text { Thermococcus aegaeus }\end{array}$ \\
\hline ArcPamv22 & KC510316 & $\begin{array}{c}100 \% 99 \% \\
\text { FJ755715 }\end{array}$ & $\begin{array}{c}85 \% 80 \% \\
\text { NR028179 } \\
\text { Thermococcus thioreducens OGL-20P }\end{array}$ \\
\hline ArcPamv23 & KC510317 & $\begin{array}{l}100 \% 99 \% \\
\text { HM } 244131\end{array}$ & $\begin{array}{c}100 \% 95 \% \\
\text { NR044422 } \\
\text { Methanosphaerula palustris strain E1-9c }\end{array}$ \\
\hline ArcPamv24 & KC510318 & $\begin{array}{l}100 \% 99 \% \\
\text { HQ330702 }\end{array}$ & $\begin{array}{c}100 \% 93 \% \\
\text { NR044422 } \\
\text { Methanosphaerula palustris strain E1-9c }\end{array}$ \\
\hline
\end{tabular}




\section{Continued}

\begin{tabular}{|c|c|c|c|}
\hline ArcPamv25 & KC510319 & $\begin{array}{l}100 \% 99 \% \\
\text { JQ245676 }\end{array}$ & $\begin{array}{c}100 \% 94 \% \\
\text { NR044422 } \\
\text { Methanosphaerula palustris strain E1-9c }\end{array}$ \\
\hline ArcPamv28 & KC510320 & $\begin{array}{c}100 \% 99 \% \\
\text { DQ676243 }\end{array}$ & $\begin{array}{c}100 \% 95 \% \\
\text { NR044422 } \\
\text { Methanosphaerula palustris strain E1-9c }\end{array}$ \\
\hline ArcPamv29 & KC510321 & $\begin{array}{c}100 \% 99 \% \\
\text { HQ330690 }\end{array}$ & $\begin{array}{c}90 \% 92 \% \\
\text { NR042740 } \\
\text { Thermococcus hydrothermalis strain AL662 }\end{array}$ \\
\hline ArcPamv30 & KC510322 & $\begin{array}{c}100 \% 99 \% \\
\text { HQ330690 }\end{array}$ & $\begin{array}{c}85 \% 81 \% \\
\text { NR028179 } \\
\text { Thermococcus thioreducens OGL-20P }\end{array}$ \\
\hline ArcPamv31 & KC510323 & $\begin{array}{c}100 \% 99 \% \\
\text { DQ785302 }\end{array}$ & $\begin{array}{c}100 \% 94 \% \\
\text { NR028163 } \\
\text { Methanolinea tarda NOBI-1 }\end{array}$ \\
\hline ArcPamv33 & KC510324 & $\begin{array}{c}100 \% 98 \% \\
\text { JF262336 }\end{array}$ & $\begin{array}{c}100 \% 96 \% \\
\text { NR028163 } \\
\text { Methanolinea tarda NOBI-1 }\end{array}$ \\
\hline ArcPamv35 & KC510325 & $\begin{array}{l}100 \% 97 \% \\
\text { JQ792848 }\end{array}$ & $\begin{array}{c}100 \% 78 \% \\
\text { NR028248 } \\
\text { Methanothermobacter defluvii }\end{array}$ \\
\hline ArcPamv36 & KC510326 & $\begin{array}{c}100 \% 92 \% \\
\text { JF853612 }\end{array}$ & $\begin{array}{c}100 \% 78 \% \\
\text { NR043089 } \\
\text { Methanomethylovorans thermophila }\end{array}$ \\
\hline ArcPamv37 & KC510327 & $\begin{array}{c}100 \% 99 \% \\
\text { FJ755715 }\end{array}$ & $\begin{array}{c}90 \% 92 \% \\
\text { NR028179 } \\
\text { Thermococcus thioreducens } \text { OGL-20P }\end{array}$ \\
\hline ArcPamv38 & KC510328 & $\begin{array}{c}100 \% 100 \% \\
\text { FJ755715 }\end{array}$ & $\begin{array}{c}90 \% 92 \% \\
\text { NR028179 } \\
\text { Thermococcus thioreducens OGL-20P }\end{array}$ \\
\hline ArcPamv39 & KC510329 & $\begin{array}{l}100 \% 99 \% \\
\text { JQ079951 }\end{array}$ & $\begin{array}{c}100 \% 98 \% \\
\text { NR028242 } \\
\text { Methanosaeta concilii strain Opfikon }\end{array}$ \\
\hline ArcPamv42 & KC510330 & $\begin{array}{l}\text { 99\% 99\% } \\
\text { JQ794950 }\end{array}$ & $\begin{array}{c}99 \% 97 \% \\
\text { NR028163 } \\
\text { Methanolinea tarda NOBI-1 }\end{array}$ \\
\hline ArcPamv43 & KC510331 & $\begin{array}{l}99 \% 99 \% \\
J X 426879\end{array}$ & $\begin{array}{c}99 \% 96 \% \\
\text { NR044422 } \\
\text { Methanosphaerula palustris strain E1-9c }\end{array}$ \\
\hline ArcPamv44 & KC510332 & $\begin{array}{c}\text { 99\% 98\% } \\
\text { LN896671 }\end{array}$ & $\begin{array}{c}99 \% 76 \% \\
\text { NR029140 } \\
\text { Methanococcus aeolicus NanKai-3 }\end{array}$ \\
\hline ArcPamv45 & KC510333 & $\begin{array}{l}94 \% 98 \% \\
\text { AJ } 240005 \\
97 \% 96 \% \\
\text { AF005766 }\end{array}$ & $\begin{array}{c}94 \% 100 \% \\
\text { NR029214 } \\
\text { Thermofilum pendens strain Hvv3, DSM } 2474 \\
94 \% 100 \% \\
\text { NR028877 }\end{array}$ \\
\hline & & & Staphylothermus hellenicus DSM 12710 strain P8 \\
\hline
\end{tabular}




\section{Continued}

\begin{tabular}{|c|c|c|c|}
\hline ArcPamv49 & KC510334 & $\begin{array}{c}100 \% 98 \% \\
\text { JF980361 }\end{array}$ & $\begin{array}{c}100 \% 95 \% \\
\text { NR044422 } \\
\text { Methanosphaerula palustris strain E1-9c }\end{array}$ \\
\hline ArcPamv51A & KC510335 & $\begin{array}{c}100 \% 99 \% \\
J F 431901\end{array}$ & $\begin{array}{c}100 \% 80 \% \\
\text { NR042784 } \\
\text { Methanobrevibacter ruminantium M1 strain M1 }\end{array}$ \\
\hline ArcPamv51B & KC510336 & $\begin{array}{l}99 \% 98 \% \\
\text { JQ794997 }\end{array}$ & $\begin{array}{c}99 \% 94 \% \\
\text { NR044422 } \\
\text { Methanosphaerula palustris strain E1-9c }\end{array}$ \\
\hline ArcPamv52 & KC510337 & $\begin{array}{c}100 \% 99 \% \\
\text { HM244091 }\end{array}$ & $\begin{array}{c}100 \% 80 \% \\
\text { NR042784 } \\
\text { Methanobrevibacter ruminantium M1 strain M1 }\end{array}$ \\
\hline ArcPamv54 & KC510338 & $\begin{array}{c}100 \% 99 \% \\
\text { JF431775 }\end{array}$ & $\begin{array}{c}99 \% 83 \% \\
\text { NR043512 } \\
\text { Ignisphaera aggregans DSM } 17230 \text { strain AQ1.S1 }\end{array}$ \\
\hline ArcPamv55 & KC510339 & $\begin{array}{l}100 \% 99 \% \\
\text { FM165672 }\end{array}$ & $\begin{array}{c}100 \% 96 \% \\
\text { NR044422 } \\
\text { Methanosphaerula palustris strain E1-9c }\end{array}$ \\
\hline ArcPamv57 & KC510340 & $\begin{array}{l}99 \% 99 \% \\
\text { JQ794950 }\end{array}$ & $\begin{array}{c}99 \% 96 \% \\
\text { NR028163 } \\
\text { Methanolinea tarda NOBI-1 }\end{array}$ \\
\hline ArcPamv58A & KC510341 & $\begin{array}{l}99 \% 99 \% \\
\text { JN649164 }\end{array}$ & $\begin{array}{c}99 \% 95 \% \\
\text { NR044422 } \\
\text { Methanosphaerula palustris strain E1-9c }\end{array}$ \\
\hline ArcPamv58B & KC510342 & $\begin{array}{c}99 \% 96 \% \\
\text { FN432722 }\end{array}$ & $\begin{array}{c}99 \% 78 \% \\
\text { NR042734 } \\
\text { Thermococcus barophilus MP strain DSM } 11836\end{array}$ \\
\hline ArcPamv59 & KC510343 & $\begin{array}{c}99 \% 97 \% \\
\text { HQ330736 }\end{array}$ & $\begin{array}{c}100 \% 78 \% \\
\text { NR025718 } \\
\text { Methanococcus vannielii strain 5B }\end{array}$ \\
\hline ArcPamv60 & KC510344 & $\begin{array}{l}100 \% 99 \% \\
\text { DQ310455 }\end{array}$ & $\begin{array}{c}100 \% 77 \% \\
\text { NR028210 } \\
\text { Ferroplasma cupricumulans } \mathrm{BH} 2\end{array}$ \\
\hline ArcPamv65A & KC510345 & $\begin{array}{c}100 \% 90 \% \\
\text { HM004825 }\end{array}$ & $\begin{array}{c}100 \% 78 \% \\
\text { NR029140 } \\
\text { Methanococcus aeolicus NanKai-3 }\end{array}$ \\
\hline ArcPamv65B & KC510346 & $\begin{array}{c}100 \% 97 \% \\
\text { FJ755715 }\end{array}$ & $\begin{array}{c}100 \% 78 \% \\
\text { NR042781 } \\
\text { Methanobacterium bryantii strain MOH }\end{array}$ \\
\hline ArcPamv66 & KC510347 & $\begin{array}{c}98 \% 93 \% \\
\mathrm{AB} 653407\end{array}$ & $\begin{array}{c}100 \% 78 \% \\
\text { NR041513 } \\
\text { Thermogymnomonas acidicola strain JCM } 13583\end{array}$ \\
\hline ArcPamv67A & KC510348 & $\begin{array}{l}100 \% 99 \% \\
\text { HE796161 }\end{array}$ & $\begin{array}{c}100 \% 78 \% \\
\text { NR028701 } \\
\text { Methanocaldococcus vulcanius M7 }\end{array}$ \\
\hline ArcPamv67B & KC510349 & $\begin{array}{c}100 \% 99 \% \\
\text { HQ404340 }\end{array}$ & $\begin{array}{c}100 \% 77 \% \\
\text { NR028646 } \\
\text { Methanotorris formicicus strain Mc-S-70 }\end{array}$ \\
\hline
\end{tabular}




\section{Continued}

\begin{tabular}{|c|c|c|c|}
\hline ArcPamv69 & KC510350 & $\begin{array}{l}100 \% 99 \% \\
\text { JN853654 }\end{array}$ & $\begin{array}{c}100 \% 80 \% \\
\text { NR042784 } \\
\text { Methanobrevibacter ruminantinum M1 }\end{array}$ \\
\hline ArcPamv70 & KC510351 & $\begin{array}{l}99 \% 100 \% \\
\text { AB652545 }\end{array}$ & $\begin{array}{c}100 \% 93 \% \\
\text { NR028164 } \\
\text { Methanocella paludicola SANAE }\end{array}$ \\
\hline ArcPamv71 & KC510352 & $\begin{array}{l}100 \% 90 \% \\
\text { EF639526 }\end{array}$ & $\begin{array}{c}100 \% 80 \% \\
\text { NR044786 } \\
\text { Methanobrevibacter smithii ATCC } 35061\end{array}$ \\
\hline ArcPamv72A & KC510353 & $\begin{array}{l}100 \% 98 \% \\
\text { JQ595987 }\end{array}$ & $\begin{array}{c}100 \% 95 \% \\
\text { NR042789 } \\
\text { Methanospirillum hungatei JF-1, strain JF1 }\end{array}$ \\
\hline ArcPamv72B & KC510354 & $\begin{array}{c}100 \% 99 \% \\
\text { DQ785302 }\end{array}$ & $\begin{array}{c}100 \% 94 \% \\
\text { NR044422 } \\
\text { Methanosphaerula palustris strain E1-9c }\end{array}$ \\
\hline ArcPamv75 & KC510355 & $\begin{array}{l}100 \% 96 \% \\
\text { JN649130 }\end{array}$ & $\begin{array}{c}100 \% 94 \% \\
\text { NR043961 } \\
\text { Methanoculleus receptaculi }\end{array}$ \\
\hline ArcPamv76 & KC510356 & $\begin{array}{l}100 \% 99 \% \\
\text { AB775723 }\end{array}$ & $\begin{array}{c}100 \% 97 \% \\
\text { NR028163 } \\
\text { Methanolinea tarda NOBI-1 }\end{array}$ \\
\hline ArcPamv77A & KC510357 & $\begin{array}{c}100 \% 99 \% \\
\text { JQ794950 }\end{array}$ & $\begin{array}{c}100 \% 96 \% \\
\text { NR028163 } \\
\text { Methanolinea tarda NOBI-1 }\end{array}$ \\
\hline ArcPamv77B & KC510358 & $\begin{array}{c}99 \% 97 \% \\
\text { FN646492 }\end{array}$ & $\begin{array}{c}99 \% 92 \% \\
\text { NR044422 } \\
\text { Methanosphaerula palustris E1-9c }\end{array}$ \\
\hline ArcPamv79A & KC510359 & $\begin{array}{l}100 \% 96 \% \\
\text { JN853749 }\end{array}$ & $\begin{array}{c}100 \% 78 \% \\
\text { NR029059 } \\
\text { Palaeococcus helgesonii }\end{array}$ \\
\hline ArcPamv79B & KC510360 & $\begin{array}{c}100 \% 99 \% \\
\text { JX426833 }\end{array}$ & $\begin{array}{c}100 \% 96 \% \\
\text { NR044422 } \\
\text { Methanosphaerula palustris E1-9c }\end{array}$ \\
\hline ArcPamv79C & KC510361 & $\begin{array}{c}100 \% 99 \% \\
\text { JQ792430 }\end{array}$ & $\begin{array}{c}100 \% 96 \% \\
\text { NR044422 } \\
\text { Methanosphaerula palustris E1-9c }\end{array}$ \\
\hline ArcPamv79D & KC510362 & $\begin{array}{c}97 \% 99 \% \\
\text { HQ330660 }\end{array}$ & $\begin{array}{c}97 \% 95 \% \\
\text { NR044422 } \\
\text { Methanosphaerula palustris E1-9c }\end{array}$ \\
\hline ArcPamv82 & KC510363 & $\begin{array}{c}100 \% 99 \% \\
\text { JX426833 }\end{array}$ & $\begin{array}{c}100 \% 96 \% \\
\text { NR044422 } \\
\text { Methanosphaerula palustris E1-9c }\end{array}$ \\
\hline ArcPamv83A & KC510364 & $\begin{array}{c}99 \% 98 \% \\
\text { EF639443 }\end{array}$ & $\begin{array}{c}99 \% 93 \% \\
\text { NR044422 } \\
\text { Methanosphaerula palustris E1-9c }\end{array}$ \\
\hline
\end{tabular}




\section{Continued}

\begin{tabular}{|c|c|c|c|}
\hline ArcPamv83B & KC510365 & $\begin{array}{c}100 \% 99 \% \\
\text { JQ245676 }\end{array}$ & $\begin{array}{c}100 \% 94 \% \\
\text { NR028163 } \\
\text { Methanolinea tarda NOBI-1 }\end{array}$ \\
\hline ArcPamv84A & KC510366 & $\begin{array}{l}100 \% 99 \% \\
\text { JQ245676 }\end{array}$ & $\begin{array}{c}100 \% 94 \% \\
\text { NR0128163 } \\
\text { Methanolinea tarda NOBI-1 }\end{array}$ \\
\hline ArcPamv84B & KC510367 & $\begin{array}{c}87 \% 87 \% \\
\text { HQ330736 } \\
97 \% 76 \% \\
\text { EU983178 }\end{array}$ & $\begin{array}{c}82 \% 76 \% \\
\text { NR102915 } \\
\text { Methanothermococcus okinawensis IH } 1\end{array}$ \\
\hline ArcPamv86A & KC510368 & $\begin{array}{l}100 \% 99 \% \\
\text { JN617381 }\end{array}$ & $\begin{array}{c}100 \% 80 \% \\
\text { NR074217 } \\
\text { Aciduliprofundum boonei T469 strain T469 }\end{array}$ \\
\hline ArcPamv86B & KC510369 & $\begin{array}{c}99 \% 97 \% \\
\text { EU519275 }\end{array}$ & $\begin{array}{c}99 \% 95 \% \\
\text { NR044422 } \\
\text { Methanosphaerula palustris E1-9c }\end{array}$ \\
\hline ArcPamv88 & KC510370 & $\begin{array}{l}98 \% 99 \% \\
J F 431886\end{array}$ & $\begin{array}{c}98 \% 98 \% \\
\text { NR028242 } \\
\text { Methanosaeta concilii strain Opfikon }\end{array}$ \\
\hline ArcPamv89 & KC510371 & $\begin{array}{l}100 \% 96 \% \\
\text { JQ792848 }\end{array}$ & $\begin{array}{c}100 \% 78 \% \\
\text { NR116289 } \\
\text { Methanobacterium movens strain TS-2 }\end{array}$ \\
\hline ArcPamv90 & KC510372 & $\begin{array}{l}100 \% 97 \% \\
\text { FN646483 }\end{array}$ & $\begin{array}{c}100 \% 93 \% \\
\text { NR028242 } \\
\text { Methanosaeta concilii Opfikon }\end{array}$ \\
\hline ArcPamv92 & KC510373 & $\begin{array}{l}\text { 100\% 99\% } \\
\text { JQ079951 }\end{array}$ & $\begin{array}{c}100 \% 98 \% \\
\text { NR028242 } \\
\text { Methanosaeta concilii Opfikon }\end{array}$ \\
\hline ArcPamv96 & KC510374 & $\begin{array}{l}100 \% 99 \% \\
\text { HE964957 }\end{array}$ & $\begin{array}{c}100 \% 94 \% \\
\text { NR028242 } \\
\text { Methanosaeta concilii Opfikon }\end{array}$ \\
\hline ArcPamv108A & KC510375 & $\begin{array}{c}100 \% 99 \% \\
\text { HQ330667 }\end{array}$ & $\begin{array}{c}100 \% 94 \% \\
\text { NR044422 } \\
\text { Methanosphaerula palustris E1-9c }\end{array}$ \\
\hline ArcPamv108B & KC510376 & $\begin{array}{l}99 \% 99 \% \\
J X 426828\end{array}$ & $\begin{array}{c}99 \% 80 \% \\
\text { NR0 } 42784 \\
\text { Methanobrevibacter ruminantium M1 }\end{array}$ \\
\hline ArcPamv109 & KC510377 & $\begin{array}{c}100 \% 99 \% \\
\text { HQ330667 }\end{array}$ & $\begin{array}{c}100 \% 95 \% \\
\text { NR044422 } \\
\text { Methanosphaerula palustris E1-9c }\end{array}$ \\
\hline ArcPamv112 & KC510378 & $\begin{array}{c}100 \% 99 \% \\
\text { HQ330702 }\end{array}$ & $\begin{array}{c}100 \% 93 \% \\
\text { NR044422 } \\
\text { Methanosphaerula palustris E1-9c }\end{array}$ \\
\hline ArcPamv114 & KC510379 & $\begin{array}{c}100 \% 99 \% \\
\text { HM } 244128\end{array}$ & $\begin{array}{c}100 \% 84 \% \\
\text { NR028877 } \\
\text { Staphylothermus hellenicus DSM } 12710 \text { strain P8 }\end{array}$ \\
\hline ArcPamv115 & KC510380 & $\begin{array}{c}99 \% 98 \% \\
\text { FN646492 }\end{array}$ & $\begin{array}{c}99 \% 92 \% \\
\text { NR04442 } \\
\text { Methanosphaerula palustris E1-9c }\end{array}$ \\
\hline
\end{tabular}


Table S5. Distribution of archaeal 16S rDNA clones in Lake Pamvotis sample stations.

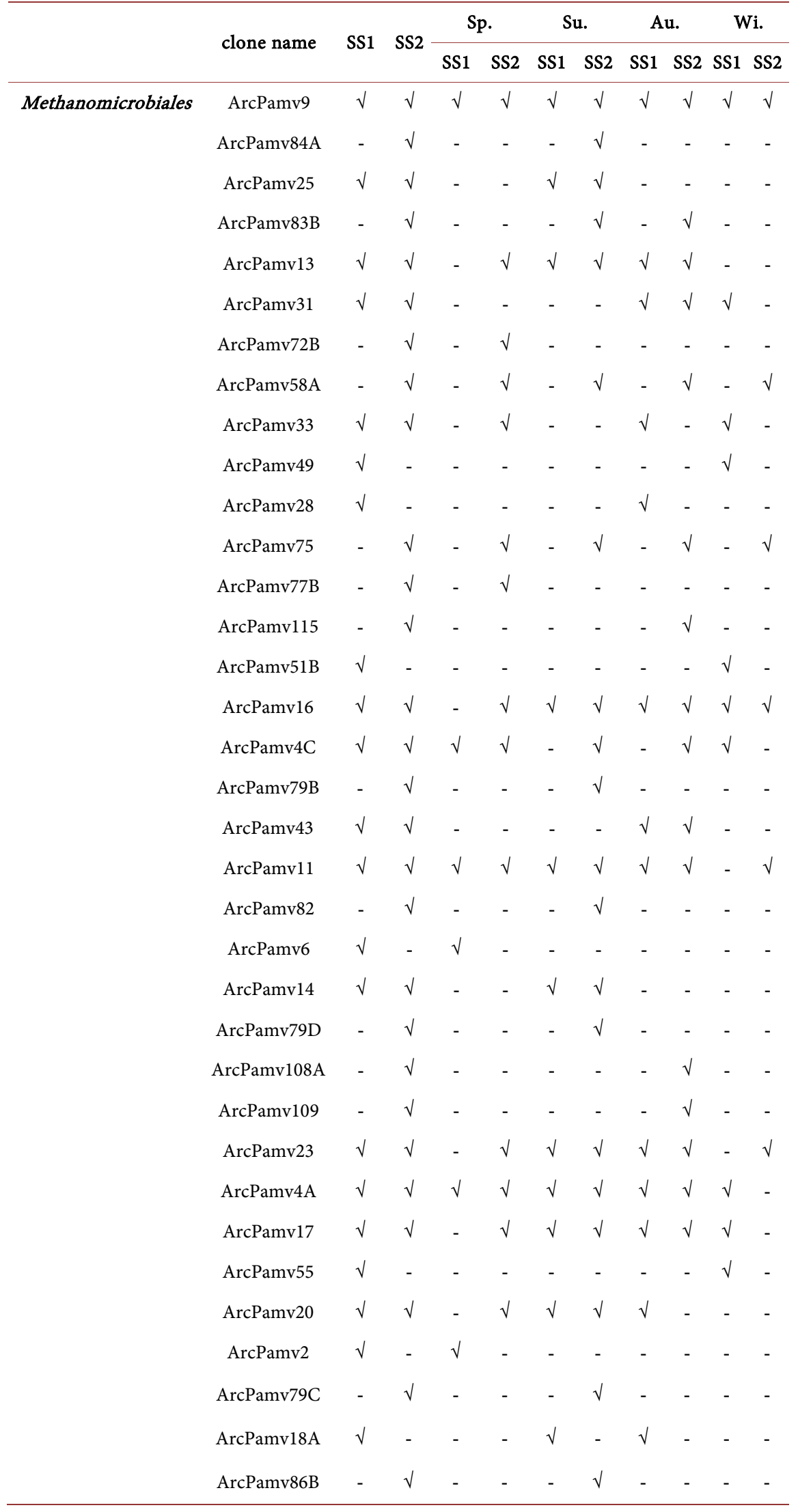




\section{Continued}

\begin{tabular}{|c|c|c|c|c|c|c|c|c|c|c|c|}
\hline & ArcPamv76 & - & $\sqrt{ }$ & - & $\sqrt{ }$ & - & - & - & - & - & - \\
\hline & ArcPamv7 & $\sqrt{ }$ & $\sqrt{ }$ & $\sqrt{ }$ & $\sqrt{ }$ & $\sqrt{ }$ & $\sqrt{ }$ & $\sqrt{ }$ & $\sqrt{ }$ & $\sqrt{ }$ & $\sqrt{ }$ \\
\hline & ArcPamv12 & $\sqrt{ }$ & - & - & - & $\sqrt{ }$ & - & - & - & - & - \\
\hline & ArcPamv42 & $\sqrt{ }$ & - & - & - & - & - & $\sqrt{ }$ & - & - & - \\
\hline & ArcPamv57 & $\sqrt{ }$ & - & - & - & - & - & - & - & $\sqrt{ }$ & - \\
\hline & ArcPamv10 & $\sqrt{ }$ & $\sqrt{ }$ & $\sqrt{ }$ & $\sqrt{ }$ & $\sqrt{ }$ & $\sqrt{ }$ & $\sqrt{ }$ & $\sqrt{ }$ & $\sqrt{ }$ & $\sqrt{ }$ \\
\hline & ArcPamv77A & - & $\sqrt{ }$ & - & $\sqrt{ }$ & - & - & - & - & - & - \\
\hline & ArcPamv1 & $\sqrt{ }$ & - & $\sqrt{ }$ & - & - & - & - & - & - & - \\
\hline & ArcPamv83A & - & $\sqrt{ }$ & - & - & - & $\sqrt{ }$ & - & - & - & - \\
\hline & ArcPamv24 & $\sqrt{ }$ & $\sqrt{ }$ & - & $\sqrt{ }$ & $\sqrt{ }$ & $\sqrt{ }$ & $\sqrt{ }$ & $\sqrt{ }$ & $\sqrt{ }$ & $\sqrt{ }$ \\
\hline & ArcPamv15 & $\sqrt{ }$ & $\sqrt{ }$ & - & $\sqrt{ }$ & $\sqrt{ }$ & $\sqrt{ }$ & $\sqrt{ }$ & $\sqrt{ }$ & $\sqrt{ }$ & $\sqrt{ }$ \\
\hline & ArcPamv12 & $\sqrt{ }$ & - & - & - & $\sqrt{ }$ & - & - & - & - & - \\
\hline & ArcPamv72A & - & $\sqrt{ }$ & - & $\sqrt{ }$ & - & - & - & - & - & - \\
\hline & ArcPamv90 & - & $\sqrt{ }$ & - & - & - & $\sqrt{ }$ & - & - & - & - \\
\hline & ArcPamv70 & - & $\sqrt{ }$ & - & $\sqrt{ }$ & - & - & - & $\sqrt{ }$ & - & - \\
\hline & ArcPamv96 & - & $\sqrt{ }$ & - & - & - & $\sqrt{ }$ & - & - & - & - \\
\hline & ArcPamv5 & $\sqrt{ }$ & $\sqrt{ }$ & $\sqrt{ }$ & $\sqrt{ }$ & $\sqrt{ }$ & $\sqrt{ }$ & $\sqrt{ }$ & $\sqrt{ }$ & $\sqrt{ }$ & $\sqrt{ }$ \\
\hline & ArcPamv92 & - & $\sqrt{ }$ & - & - & - & $\sqrt{ }$ & - & $\sqrt{ }$ & - & $\sqrt{ }$ \\
\hline & ArcPamv39 & $\sqrt{ }$ & - & - & - & - & - & $\sqrt{ }$ & - & - & - \\
\hline & ArcPamv88 & - & $\sqrt{ }$ & - & - & - & $\sqrt{ }$ & - & $\sqrt{ }$ & - & - \\
\hline TOTAL SEQUENCES & & 32 & 42 & 10 & 23 & 18 & 30 & 20 & 24 & 16 & 12 \\
\hline \multirow[t]{3}{*}{$\begin{array}{l}\text { Miscellaneous } \\
\text { Crenarchaeota }\end{array}$} & ArcPamv54 & $\sqrt{ }$ & - & - & - & - & - & - & - & $\sqrt{ }$ & - \\
\hline & ArcPamv45 & $\sqrt{ }$ & - & - & - & - & - & - & - & $\sqrt{ }$ & - \\
\hline & ArcPamv114 & - & $\sqrt{ }$ & - & - & - & - & - & $\sqrt{ }$ & - & - \\
\hline TOTAL SEQUENCES & & 2 & 1 & 0 & 0 & 0 & 0 & 0 & 1 & 2 & 0 \\
\hline \multirow[t]{11}{*}{ Unknown cluster I } & ArcPamv35 & $\sqrt{ }$ & - & - & - & - & - & $\sqrt{ }$ & - & - & - \\
\hline & ArcPamv89 & - & $\sqrt{ }$ & - & - & - & $\sqrt{ }$ & - & $\sqrt{ }$ & - & $\sqrt{ }$ \\
\hline & ArcPamv29 & $\sqrt{ }$ & - & - & - & - & - & $\sqrt{ }$ & - & - & - \\
\hline & ArcPamv58B & - & $\sqrt{ }$ & - & $\sqrt{ }$ & - & $\sqrt{ }$ & - & - & - & - \\
\hline & ArcPamv79A & - & $\sqrt{ }$ & - & - & - & $\sqrt{ }$ & - & - & - & - \\
\hline & ArcPamv30 & $\sqrt{ }$ & - & - & - & - & - & $\sqrt{ }$ & - & - & - \\
\hline & ArcPamv65B & - & $\sqrt{ }$ & - & $\sqrt{ }$ & - & - & - & - & - & - \\
\hline & ArcPamv8B & $\sqrt{ }$ & - & $\sqrt{ }$ & - & - & - & - & - & $\sqrt{ }$ & - \\
\hline & ArcPamv22 & $\sqrt{ }$ & - & - & - & $\sqrt{ }$ & - & $\sqrt{ }$ & - & - & - \\
\hline & ArcPamv37 & $\sqrt{ }$ & - & - & - & - & - & $\sqrt{ }$ & - & - & - \\
\hline & ArcPamv38 & $\sqrt{ }$ & $\sqrt{ }$ & - & $\sqrt{ }$ & - & $\sqrt{ }$ & $\sqrt{ }$ & - & - & - \\
\hline
\end{tabular}




\section{Continued}

\begin{tabular}{|c|c|c|c|c|c|c|c|c|c|c|c|}
\hline$\underline{\text { TOTAL SEQUENCES }}$ & & 7 & 5 & 1 & 3 & 1 & 4 & 6 & 1 & 1 & 1 \\
\hline Unknown cluster II & ArcPamv36 & $\sqrt{ }$ & - & - & - & - & - & $\sqrt{ }$ & - & - & - \\
\hline TOTAL SEQUENCES & & 1 & 0 & 0 & 0 & 0 & 0 & 1 & 0 & 0 & 0 \\
\hline Unknown cluster III & ArcPamv21C & $\sqrt{ }$ & - & - & - & $\sqrt{ }$ & - & $\sqrt{ }$ & - & - & - \\
\hline TOTAL SEQUENCES & & 1 & 0 & 0 & 0 & 1 & 0 & 1 & 0 & 0 & 0 \\
\hline Unidentified & ArcPamv71 & - & $\sqrt{ }$ & - & $\sqrt{ }$ & - & - & - & - & - & - \\
\hline TOTAL SEQUENCES & & 0 & 1 & 0 & 1 & 0 & 0 & 0 & 0 & 0 & 0 \\
\hline Unknown cluster IV & ArcPamv3A & $\sqrt{ }$ & - & $\sqrt{ }$ & - & - & - & - & - & - & - \\
\hline$\underline{\text { TOTAL SEQUENCES }}$ & & 1 & 0 & 1 & 0 & 0 & 0 & 0 & 0 & 0 & 0 \\
\hline \multirow[t]{9}{*}{ MBG-D } & ArcPamv86A & - & $\sqrt{ }$ & - & - & - & $\sqrt{ }$ & - & $\sqrt{ }$ & - & $\sqrt{ }$ \\
\hline & ArcPamv69 & - & $\sqrt{ }$ & - & $\sqrt{ }$ & - & - & - & - & - & - \\
\hline & ArcPamv52 & $\sqrt{ }$ & - & - & - & - & - & - & - & $\sqrt{ }$ & - \\
\hline & ArcPamv108B & - & $\sqrt{ }$ & - & - & - & - & - & $\sqrt{ }$ & - & - \\
\hline & ArcPamv18B & $\sqrt{ }$ & - & - & - & $\sqrt{ }$ & - & - & - & - & - \\
\hline & ArcPamv21B & $\sqrt{ }$ & $\sqrt{ }$ & - & $\sqrt{ }$ & $\sqrt{ }$ & - & $\sqrt{ }$ & - & - & - \\
\hline & ArcPamv51A & $\sqrt{ }$ & - & - & - & - & - & - & - & $\sqrt{ }$ & - \\
\hline & ArcPamv4B & $\sqrt{ }$ & - & $\sqrt{ }$ & & $\sqrt{ }$ & - & $\sqrt{ }$ & - & - & - \\
\hline & ArcPamv21A & $\sqrt{ }$ & $\sqrt{ }$ & - & $\sqrt{ }$ & $\sqrt{ }$ & - & $\sqrt{ }$ & - & - & - \\
\hline TOTAL SEQUENCES & & 6 & 5 & 1 & 3 & 4 & 1 & 3 & 2 & 2 & 1 \\
\hline \multirow[t]{8}{*}{ Rice cluster V } & ArcPamv8A & $\sqrt{ }$ & - & $\sqrt{ }$ & - & - & - & - & - & - & - \\
\hline & ArcPamv67B & - & $\sqrt{ }$ & - & $\sqrt{ }$ & - & - & - & $\sqrt{ }$ & - & - \\
\hline & ArcPamv65A & - & $\sqrt{ }$ & - & $\sqrt{ }$ & - & - & - & $\sqrt{ }$ & - & - \\
\hline & ArcPamv60 & - & $\sqrt{ }$ & - & $\sqrt{ }$ & - & - & - & - & - & - \\
\hline & ArcPamv66 & - & $\sqrt{ }$ & - & $\sqrt{ }$ & - & - & - & - & - & - \\
\hline & ArcPamv44 & $\sqrt{ }$ & $\sqrt{ }$ & - & - & - & $\sqrt{ }$ & - & $\sqrt{ }$ & $\sqrt{ }$ & $\sqrt{ }$ \\
\hline & ArcPamv59 & - & $\sqrt{ }$ & - & $\sqrt{ }$ & - & - & - & - & - & - \\
\hline & ArcPamv84B & - & $\sqrt{ }$ & - & - & - & $\sqrt{ }$ & - & - & - & - \\
\hline$\underline{\text { TOTAL SEQUENCES }}$ & & 2 & 7 & 1 & 5 & 0 & 2 & 0 & 3 & 1 & 1 \\
\hline Unknown cluster V & ArcPamv67A & - & $\sqrt{ }$ & - & $\sqrt{ }$ & - & - & - & $\sqrt{ }$ & - & - \\
\hline$\underline{\text { TOTAL SEQUENCES }}$ & & 0 & 1 & 0 & 1 & 0 & 0 & 0 & 1 & 0 & 0 \\
\hline LDS & ArcPamv3B & $\sqrt{ }$ & - & $\sqrt{ }$ & - & - & - & - & - & - & - \\
\hline \multirow[t]{2}{*}{ TOTAL SEQUENCES } & & 1 & 0 & 1 & 0 & 0 & 0 & 0 & 0 & 0 & 0 \\
\hline & SS1 & SS2 & & & & & & & & & \\
\hline TOTAL SEQUENCES & 53 & 62 & & & & & & & & & \\
\hline
\end{tabular}

SS1: Sample Station 1

SS2: Sample Station 2

Sp.: Spring

Su.: Summer

Au.: Autumn

Wi.: Winter 